Article

\title{
Nanoscale Observations Support the Importance of Chemical Processes in Rock Decay and Rock Coating Development in Cold Climates
}

\author{
Ronald I. Dorn ${ }^{1,2, * \mathbb{C} \text { and David H. Krinsley }}{ }^{2}$ \\ 1 School of Geographical Sciences \& Urban Planning, Arizona State University, Tempe, AZ 85287-5302, USA \\ 2 Department of Geological Sciences, University of Oregon, Eugene, OR 97403, USA \\ * Correspondence: ronald.dorn@asu.edu; Tel.: +1-480-965-7533
}

Received: 21 February 2019; Accepted: 5 March 2019; Published: 9 March 2019

check for updates

\begin{abstract}
Conventional scholarship long held that rock fracturing from physical processes dominates over chemical rock decay processes in cold climates. The paradigm of the supremacy of cold-climate shattering was questioned by Rapp's discovery (1960) that the flux of dissolved solids leaving a Kärkevagge, Swedish Lapland, watershed exceeded physical denudation processes. Many others since have gone on to document the importance of chemical rock decay in all cold climate landscapes, using a wide variety of analytical approaches. This burgeoning scholarship, however, has only generated a few nanoscale studies. Thus, this paper's purpose rests in an exploration of the potential for nanoscale research to better understand chemical processes operating on rock surfaces in cold climates. Samples from several Antarctica locations, Greenland, the Tibetan Plateau, and high altitude tropical and mid-latitude mountains all illustrate ubiquitous evidence of chemical decay at the nanoscale, even though the surficial appearance of each landscape is dominated by "bare fresh rock." With the growing abundance of focused ion beam (FIB) instruments facilitating sample preparation, the hope is that that future rock decay researchers studying cold climates will add nanoscale microscopy to their bag of tools.
\end{abstract}

Keywords: Antarctica; Anthropocene; arctic; biological weathering; chemical weathering; desert varnish; frost weathering; physical weathering; rock coatings; rock varnish

\section{Forward by Ronald I. Dorn}

Dr. David Krinsley passed away 5 November 2017 at the age of 90 . His career as a geologist spanned six decades. After completing his Ph.D. at the University of Chicago, then a post-doc at Columbia University, he started the Geology Department at Queens College and eventually became its Provost during the Vietnam era. After an appointment as an Overseas Fellow at Churchill College, University of Cambridge, he took a position as chair of Geology at Arizona State University. Dave's geological research focused on diagenetic processes, including ongoing mineral decay. I met Dave in 1988 after he stepped down as chair and was immediately challenged about everything I had ever written about what Dave called "desert varnish" - questioning even my switch in terminology to rock varnish. The grilling continued until his passing. Dave retired from ASU in 1991 and moved to the University of Oregon, where we continued our collaboration, often with gifted microscopists at the CAMCOR facility. This manuscript was about a quarter finished when Dave passed away. I have done my best to stay true to our discussions in finishing this paper. 


\section{Introduction}

Joint fractures rest at the core of geomorphic weakness [1-4]. Molnar et al. ([1], p. 12) speculated that the "role of tectonics as a crusher of rock is that in those places where rock has dodged the rock crusher, it may be stronger and less easily removed by erosive agents." While tectonic deformation and other rock-forming processes generate joints [1,5-11], these initial fractures open the way for physical and chemical rock decay processes. Note that we eschew here the term "weathering," except in quotations, for reasons explained elsewhere [12] and will use instead the preferred term of rock decay.

There exists little doubt that thermal stress [13-17] and frost cracking (or frost wedging) $[18,19]$ play critical roles in cold climate geomorphic systems. The visual appearance of bare rock in alpine, arctic and Antarctic landscapes certainly encouraged the paradigm of the dominance of "physical weathering" in cold climates championed in physical geology and physical geography textbooks [20-22]. Thus, it was surprising when actual measurements in the mid-twentieth century documented the importance of chemical processes, with Rapp [23] showing that the flux of dissolved solids leaving a Kärkevagge watershed in Sweden exceeded physical denudation processes. Hall [14,24-26], Dixon [27-35], Thorn [36-38], and their collaborators followed in persistently and systematically laying an empirical and theoretical foundation for dismantling the paradigm of the dominance of "physical weathering" in cold climates. Unfortunately, there still exists the assumption by some of "minimal chemical weathering" in cold climates like Antarctica [39]. However, most scholars no longer consider biochemical and chemical rock decay processes as unimportant or even a distant second to physical rock decay, as evidenced by recent research [40-47] and Ph.D. dissertations [48] on cold-climate rock decay not having fight against those prejudiced by the old paradigm.

Nanoscale earth science methods [49-51], including studies of mineral and rock decay processes [52-60], by and large, have not yet reached cold climate rock decay research-with the prominent exception of explorations by Schindler and collaborators of anthropogenic interactions with rock surfaces [61-66]. D.H. Krinsley has been the leading pioneer in the use of nanoscale electron microscopy in the field of rock coating research [67-71], and followed by others [72-74]. Prior to his death, Krinsley had been analyzing nanoscale processes associated with cold-climate rock surface samples from alpine, arctic, and Antarctic settings provided by the second author from different sources, and J.G. Bockheim also sent Krinsley a sample of rock varnish on a desert pavement cobble from Beacon Valley, Antarctica.

Although the purpose of this paper is not to review scholarship on cold-climate rock decay research, there exists an abundance of prior research that laid the fundamental groundwork and prior context [75-88] to understand the importance of nanoscale electron microscopy. Similarly, the research conducted for this paper does not present a systematic investigation of any one cold-climate site with sufficient sampling density to make nuanced conclusions. Instead, the simple purpose of this presentation rests in illustrating the power of nanoscale electron microscopy in the study of chemical processes in cold climate regions. The findings of this paper support fully the thinking of Rapp, Hall, Dixon, Thorn, and others that chemical rock decay processes dominate rock surfaces in cold climates. The hope is that the evidence presented here encourages cold climate rock decay researchers to explore the nanoscale.

\section{Samples and Methods}

The samples analyzed in this study derive from alpine, arctic, and Antarctic settings (Table 1). The analysis of rock decay and the rock coatings formed on terrestrial surfaces requires study via electron microscopy (Table 2). Secondary electron (SE) microscopy, back-scattered electron (BSE) microscopy, and energy dispersive X-ray spectroscopy (EDX) are appropriate for micron-scale analyses. Nanoscale analyses requires higher resolution microscopy that often requires thinning samples to permit electrons to pass through them, where resolution varies from $\sim 10$ to $50 \mathrm{~nm}$, depending on the material and the techniques used. 
Table 1. Sample locations analyzed in this research.

\begin{tabular}{cccc}
\hline Figures & Glacier & Location & Rock Type \\
\hline $1,7,13$ & Greenland outlet glacier & $-63.5540,-50.5853$ & gneiss \\
1 & Greenland shoreline, near Nuuk & $64.2089,-51.6130$ & gneiss \\
2 & Sandstone, an older moraine, Beacon Valley, & $-77.8220,160.7148$ & sandstone \\
3 & Ross Desert & $35.7001,81.5803$ & andesite \\
4 & Akesu volcanic field, Tibet [89] & $19.1716,-98.6362$ & andesite \\
$5,6,9$ & Glacial Polish, Iztaccíhuatl, Mexico & $-77.8321,160.6293$ & sandstone \\
& Desert pavement [90], Beacon Valley, Ross & & granite \\
10 & Desert, Antarctica & $-77.3098,-142.1168$ & granodiorite \\
11 & Mt. Van Valkenburg, Clark Mountains, & gneiss \\
12 & Antarctica & $37.0772,-118.4722$ & gneiss \\
\hline
\end{tabular}

Table 2. Microscopy techniques employed in this research.

\begin{tabular}{|c|c|c|}
\hline Technique (and Acronym) & Information Obtained & Spatial Resolution \\
\hline $\begin{array}{l}\text { Coupled dual-beam focused ion beam } \\
\text { electron microscopy (FIB-EM) }\end{array}$ & $\begin{array}{l}\text { Used to create and image cross } \\
\text { sections in situ in TEM analyses. } \\
\text { Real time imaging in SEM mode } \\
\text { during ion milling. }\end{array}$ & $>\sim 1 \mathrm{~nm}$ \\
\hline $\begin{array}{l}\text { High resolution transmission electron } \\
\text { microscopy (HRTEM) and scanning } \\
\text { transmission electron microscopy (STEM) }\end{array}$ & 2-D spatial imaging, lattice imaging. & $>0.08 \mathrm{~nm}$ \\
\hline Energy dispersive X-ray analysis (EDX) & $\begin{array}{l}\text { Elemental composition, } \mathrm{X} \text {-ray } \\
\text { mapping of elements. }\end{array}$ & $\begin{array}{l}>1 \mathrm{~nm}(\mathrm{HRTEM}) \\
>20 \mathrm{~nm}(\mathrm{SEM})\end{array}$ \\
\hline $\begin{array}{l}\text { Scanning electron microscopy (SEM) with } \\
\text { back-scattered electron detector (BSE) }\end{array}$ & $\begin{array}{l}\text { SEM provides topographic insight, } \\
\text { while average atomic number }(\mathrm{Z}) \\
\text { revealed through contrast in } \\
\text { grayscale BSE image. }\end{array}$ & $>5 \mathrm{~nm}$ \\
\hline $\begin{array}{l}\text { Scanning electron microscopy (SEM) with } \\
\text { secondary electrons (SE) }\end{array}$ & 2-D spatial imaging. & $>1 \mathrm{~nm}$ \\
\hline
\end{tabular}

High resolution transmission electron microscopy (HRTEM) samples were prepared using a coupled dual-beam focused ion beam electron microscope (FIB-EM) to thin a region until it becomes electron transparent [91]. We also used scanning/transmission electron microscopes (TEM/STEM) where samples consist of polished cross sections, and HRTEMs of thinned lamellae that use much higher electron beam voltages (typically from 80 to $300 \mathrm{kV}$ ) than SEM. Compositional analysis employed EDX for higher atomic number elements [92]. The high voltage, along with a thinned sample, allows EDX measurements to be made with spot sizes of $<10 \mathrm{~nm}$.

A current leading technique that we would recommend for researchers exploring rock decay in cold climates would be the general category of focused-ion-beam (FIB) instruments. Sample preparation is a critical issue with decayed minerals and rock coating interactions with microorganisms. FIB instruments enable site-specific lamellae via HRTEM, STEM, and EDX (Table 2), where the lamellae can then have a large area of constant thickness. FIB instruments equipped with SEM and micromanipulators enable in situ lift-out approaches where a site of interest can be identified, cut free, and transferred directly to a TEM grid [93]. However, there exists the potential for the sample to resemble a theater curtain. Relatively new approaches to reduce curtaining have been demonstrated recently with xenon plasma focused ion beam systems for cutting large cross sections with high current beams [94].

We also used lower resolution method to examine anthropogenic lead pollution in the surface-most layer of a Greenland rock varnish, where we employed a wavelength dispersive electron microprobe to analyze lead concentrations at the micron scale. Lead is present in natural 
manganiferous varnish, but at trace element concentrations typically less than $0.03 \% \mathrm{PbO}$ [95]. Much higher abundances of lead occur in the surface-most layer of rock varnishes in warm desert settings, and this is attributed to anthropogenic practices adding lead to the atmosphere; the lead has a preference to adsorb onto the manganese and iron hydroxides in rock varnish [96-98]. Where EDX detected the presence of lead in the Greenland ice margin sample, wavelength dispersive spectroscopy (WDS) of a JEOL superprobe electron microanalyzer quantified lead abundance under operating conditions of $20 \mathrm{nA}$, a take-off angle of $40^{\circ}$, an accelerating voltage of $15 \mathrm{kv}$, and a 300 s counting time to increase sensitivity to a detection limit of about $0.03 \%$ weight $\mathrm{PbO}$.

\section{Results}

Nanoscale observations of arctic, Antarctic, and alpine cold-climate settings contextualized by micron-scale studies reveal the ubiquitous presence of chemical processes operating at rock surfaces. Even where we observed physical decay processes cracking rocks by iron hydroxides, the iron precipitation was preceded by chemical reactions that first mobilized and then reprecipitated the iron. Nanoscale processes involve a complex interaction of the accretion of rock coatings, the mobilization of rock coating material down into the underlying rock, and the chemical decay of rock minerals. A human footprint was also found in the analyzed samples, the result of direct action such as acid mine drainage and the result of global processes such as lead pollution.

\subsection{Iron Cracking as a Physiochemical Process}

Beneath the surface of iron films and rock varnishes at the ocean shoreline near Nuuk, Greenland (Figure 1), minerals experience physical cracking due to the precipitation of iron, combined with a suite of other elements. EDX elemental analyses reveal the material to be similar to many iron films, with about $20 \%$ iron, $60 \%$ clay minerals ( $\mathrm{Na}, \mathrm{Mg}$, $\mathrm{Al}$, Si peaks), and the remainder with $\mathrm{K}, \mathrm{Ti}, \mathrm{Cu}$, and $\mathrm{Zr}$ (Figure 1e). The brightness of the cracking material seen in BSE (Figure 1b-d) originates from high $\mathrm{Z}$ materials of $\mathrm{Fe}, \mathrm{Cu}$, and $\mathrm{Zr}$. The iron was remobilized from surface coatings of iron films and rock varnish, as well as Fe-bearing minerals such as magnetite (Figure 1a) and minerals too decomposed to identify with EDX (Figure 1d).

\subsection{Quartz Alteration}

Using the FIB-EM, HRTEM observations revealed two different processes of quartz alteration in an Antarctic sample from Beacon Valley (Figures 2 and 3). Nanoscale dissolution pores developed within the unaltered quartz (Figure 2b,e). Dissolution pores were more commonly close to internal fractures in the quartz. In addition, a style of alteration developed around the outer boundaries of quartz that resulted in the quartz showing an amorphous texture (Figure 2a,c), where phosphorus external to the quartz (Figure 2e) chemically reacted in such a way as to become a part of this amorphous zone (Figure 2d,f). We do not know the source of the phosphorus, but it could potentially be biologically derived from proximate rock varnish [99].

Quartz alteration had a direct effect on geomorphic interactions on the Tibetan plateau. An andesite lava flow in the Akesu volcanic field contains free quartz. The surface of the lava flow's free quartz was not a smooth surface created from conchoidal fracturing. Instead the quartz was altered in such a way as to develop a rough surface at the $<10 \mathrm{~nm}$ scale (Figure 3a). HRTEM observations reveal that the very surface consists of bumpy ridges of unaltered quartz alternating with furrows (Figure 3c) that contain phosphorus intermixed with the quartz in EDX analyses. This roughened texture enabled dust particles to adhere to the quartz surface. The attachment of dust was not a temporary condition. Rather, the surface was rough enough to allow the accretion of iron film on the dust (Figure 3a,b). 


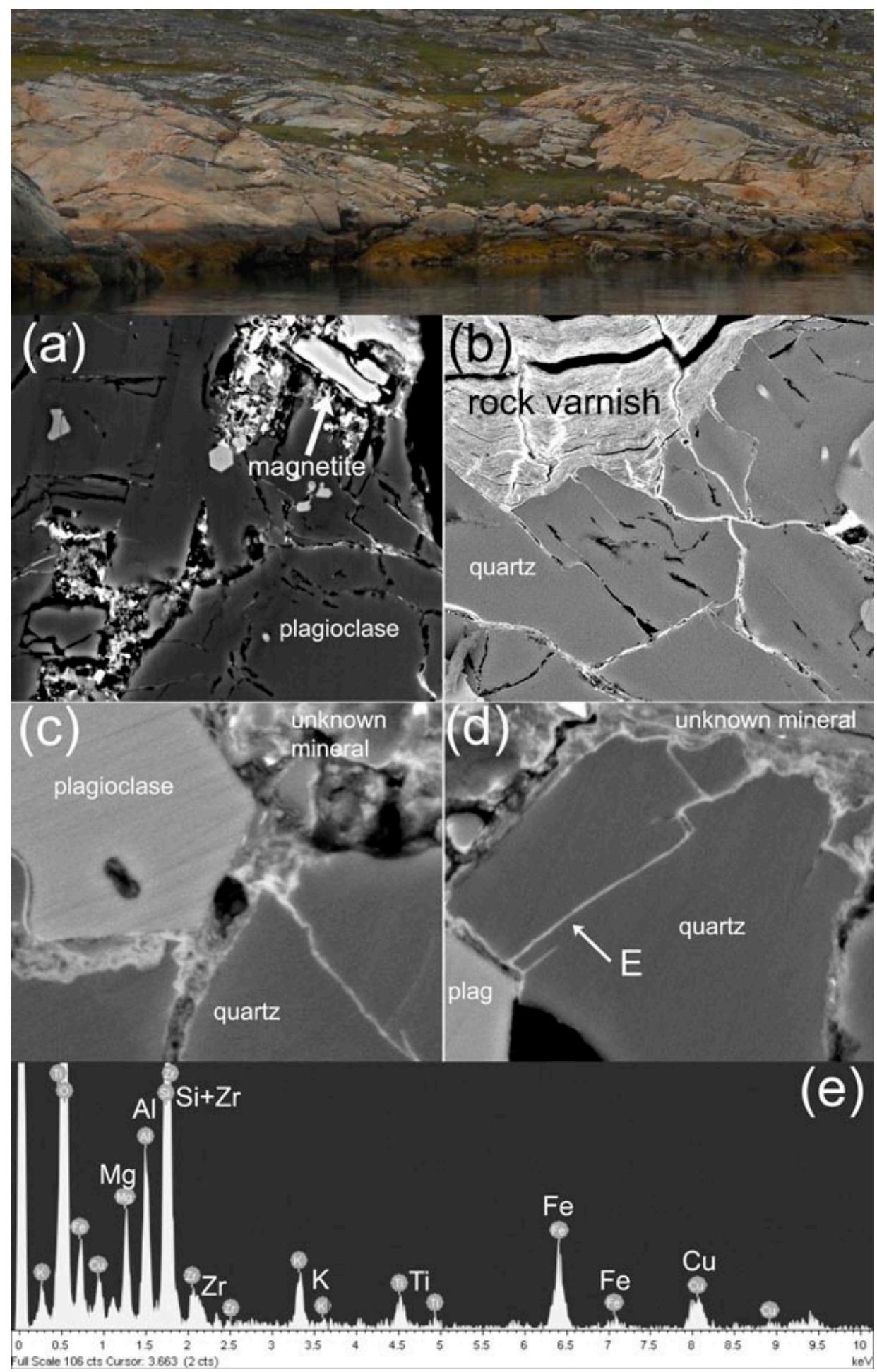

Figure 1. Orange iron films dominate near the Nuuk shoreline, while darker rock varnish occurs further away from the coast. All of the BSE images (a-d) are $120 \mu \mathrm{m}$ wide. (a) The iron derives in part from iron-rich minerals such as magnetite seen in BSE from the Nuuk shoreline, and (b) the dissolution of iron from rock varnish at the Greenland outlet glacier site. Image (b) shows quartz being split apart into silt-size fragments. Images (c) and (d) also show physical splitting of quartz at the Nuuk shoreline. (e) EDX analysis of the cracking material was from the letter $\mathrm{E}$ in image (d); the spectra reveal a mixed composition that includes $\mathrm{Fe}, \mathrm{Si}, \mathrm{Al}$, and $\mathrm{Mg}$, and smaller peaks of $\mathrm{Zr}, \mathrm{K}, \mathrm{Ti}$, and $\mathrm{Cu}$. The brightness of the line in image (d) highlighted by the arrow originates from the high atomic number elements of iron and copper. 


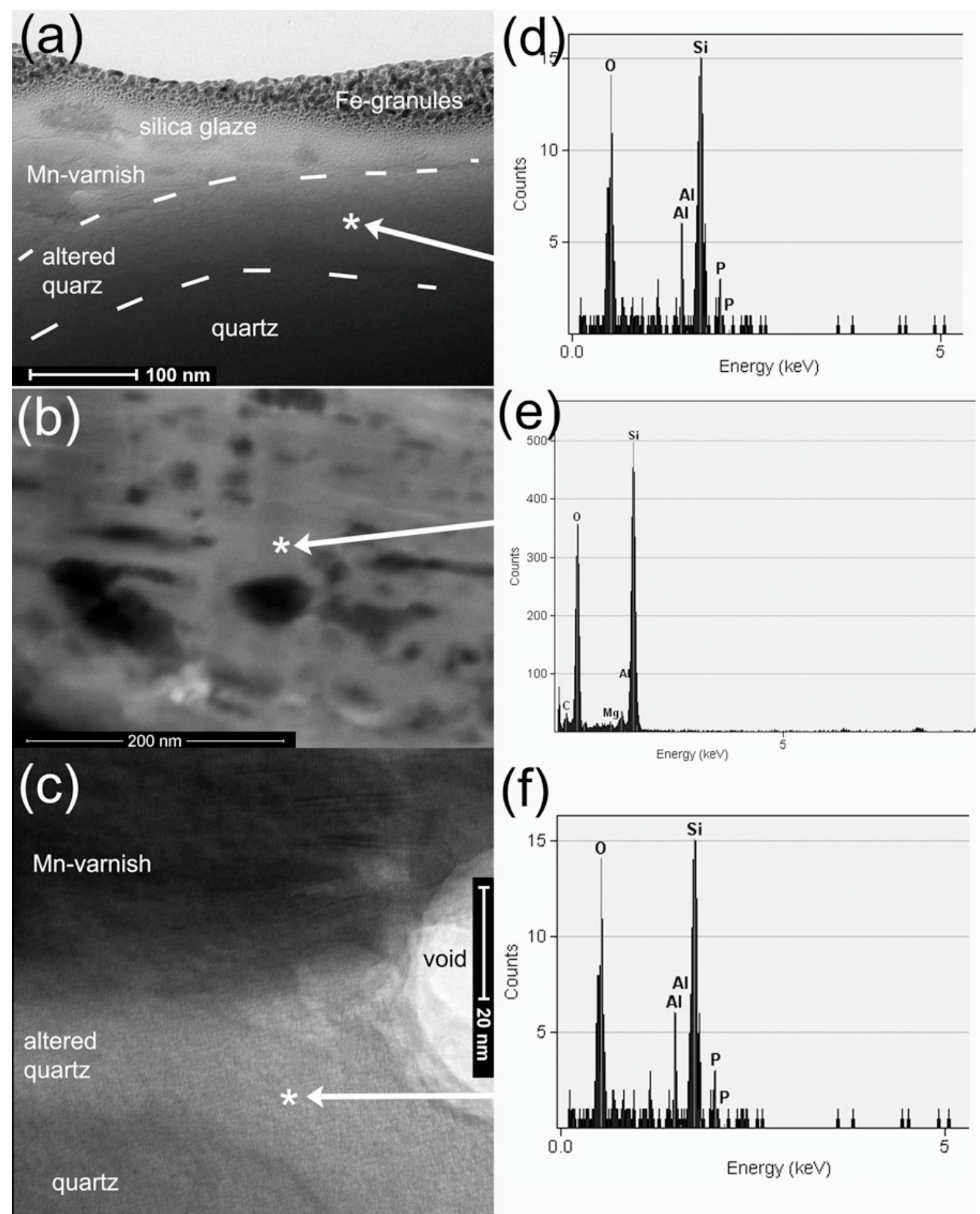

Figure 2. Alteration of quartz from Beacon Valley. (a) Altered quartz is underneath a sequence of an iron film consisting of a granular texture, silica glaze, and Mn-rich rock varnish. Between the fresh quartz and the rock coating is a zone of about $100 \mathrm{~nm}$ of alteration. (b) Some of the alteration consists of nanoscale dissolution pores, while (c) another form of alteration is similar to the hydration observed by Pope in temperate settings [59]. While the quartz itself does not contain phosphorus (e), the altered quartz does include phosphorus in EDX analyses (images $\mathbf{d}$ and $\mathbf{f}$ ). 


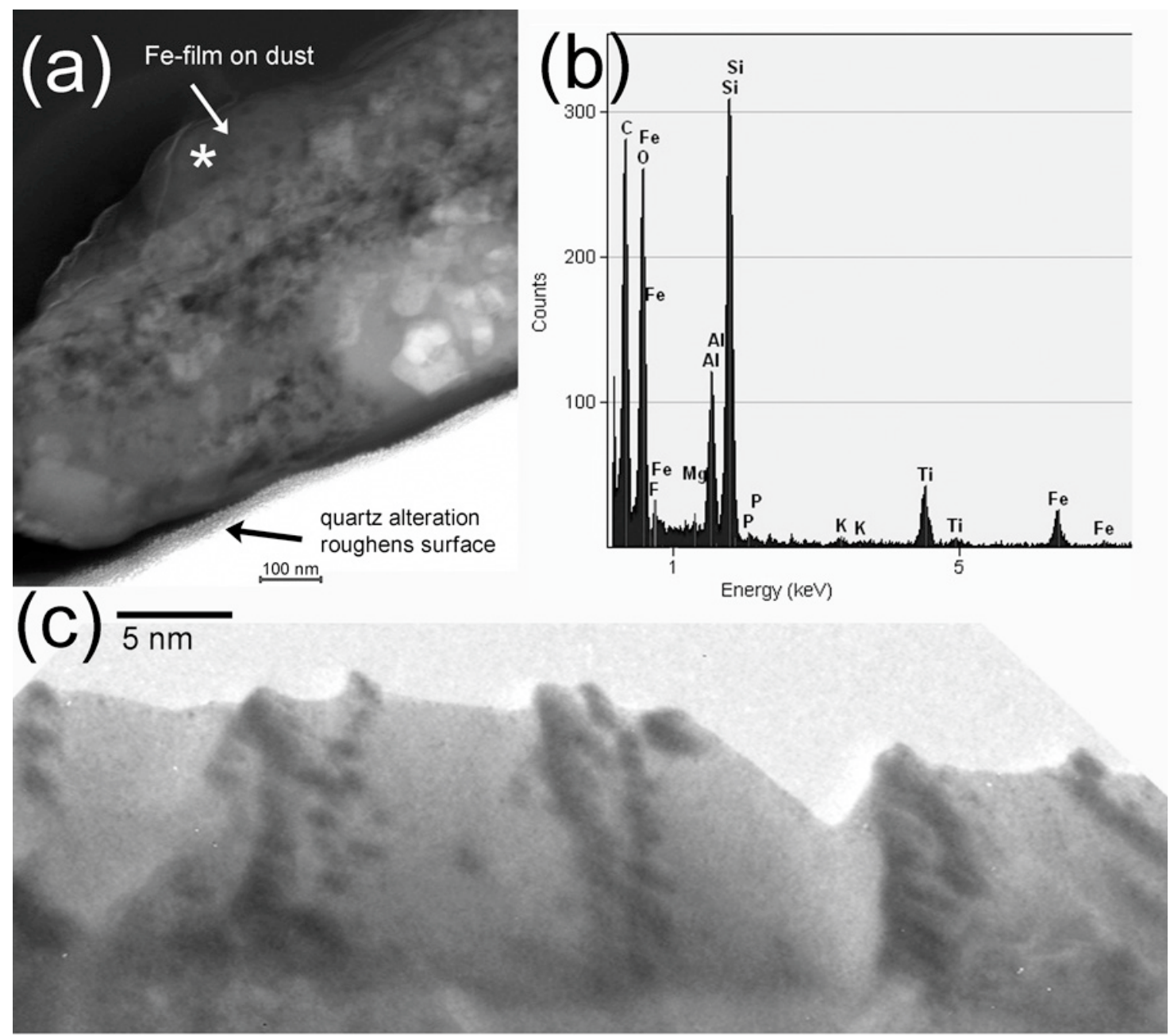

Figure 3. Alteration of free quartz on the surface of a lava flow, Akesu volcanic field, Tibet. (a) A dust particle adheres to the quartz surface that maintains a roughness from nanoscale dissolution. Note the bumpy appearance of the quartz. The dust particle has adhered to the surface long enough to accumulate a titanium-iron-rich film. (b) EDX analysis of the iron-rich film that is composed of mostly $\mathrm{Si}$ and $\mathrm{Al}$, but with major amounts of $\mathrm{Ti}$ and Fe. (c) The nanoscale surface of the quartz consists of microtopography of dissolution grooves.

\subsection{Complex Intercalation of Cold Climate Rock Coatings}

The Iztaccíhuatl volcano, Central Mexico, has a complex glacial history at high altitudes [100]. The surfaces of the Holocene moraines are commonly covered with silica glaze (Figure 4) much in the same way that the most common rock coating on Mauna Kea moraines is also silica glaze [101], but mixed with other rock coatings. Iztaccíhuatl silica glazes contain a strong aluminum peak (Figure 4d2) but with variable amounts of minor elements of $\mathrm{P}$ and Ti. Iztaccíhuatl silica glazes commonly contain internal nodules (e.g., Figure $4 \mathrm{a}-\mathrm{c}$ ) that are dominated by iron but have variable amounts of $\mathrm{Mg}, \mathrm{P}, \mathrm{Ca}$, and Mn (Figure 4d2). 

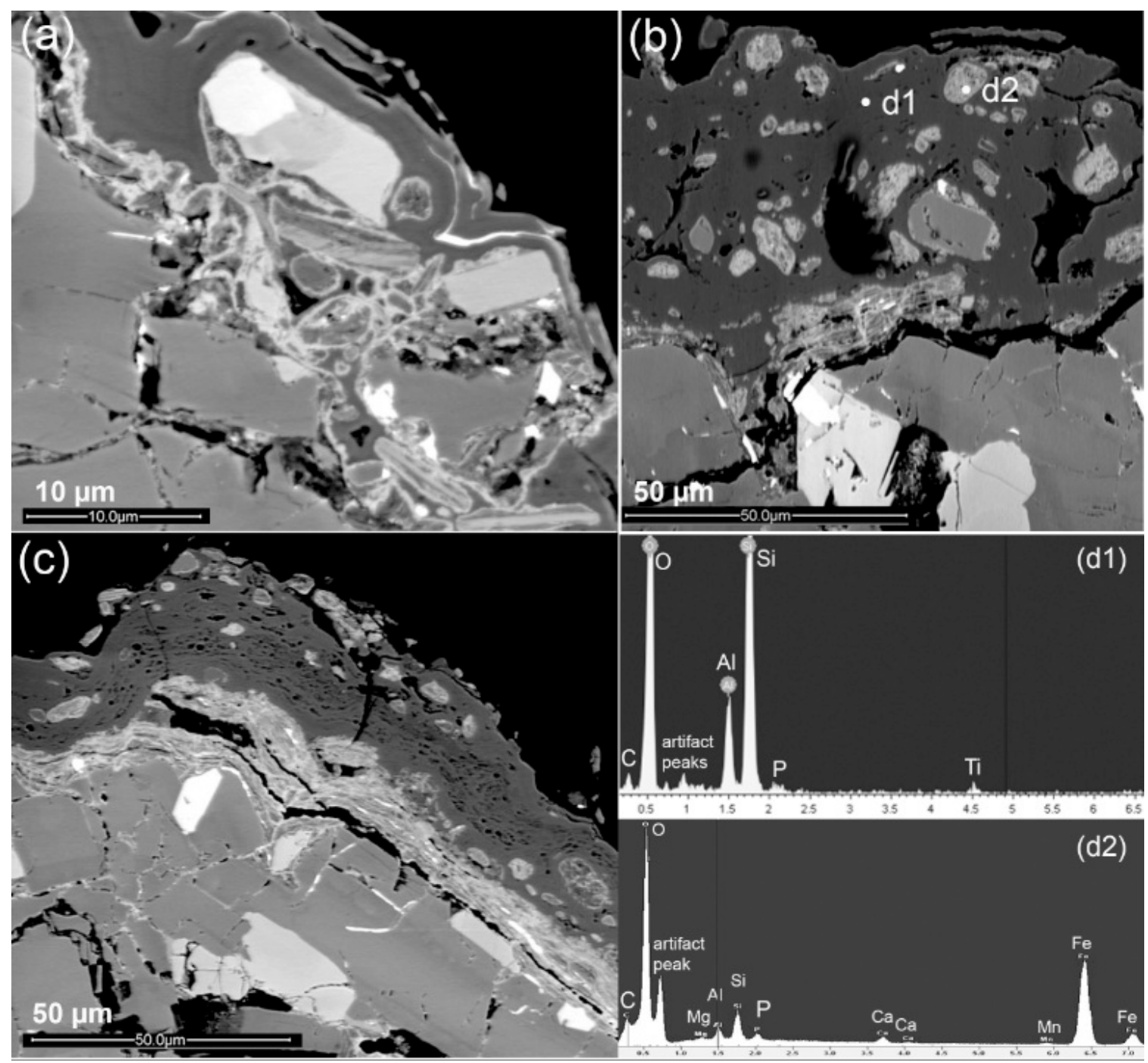

Figure 4. Silica glaze formed on glacial polish of Iztaccíhuatl, Mexico. Three BSE images (a-c) show silica glaze as the dark gray material. The silica glaze is not homogeneous. Oval zones of iron-rich material occur as discrete entities encapsulated by the silica glaze. EDX spectra in images d1 and d2 were acquired at the $\mathrm{d} 1$ (silica glaze) and $\mathbf{d} \mathbf{2}$ (iron-rich micronodule) spots indicated in image (b).

Several different types of silica glazes were observed in Antarctic samples from Beacon Valley, Ross Desert (Figures 2a, 5c and 6a). In FIB-EM imagery, some of the silica glaze appears to have incorporated 10-nm-scale iron granules (Figure 2a). Another texture consists of 40-nm-scale spheroids (Silica Glaze 2 in Figure 5c) that have EDX spectra indicating that a combination of aluminum glaze and silica glaze (Figure 5d). A third texture is more homogeneous (Silica Glaze 1 in Figure 5c) and is dominated by Si, with minor amounts of $\mathrm{Al}$ and Fe (Figure 5e). 


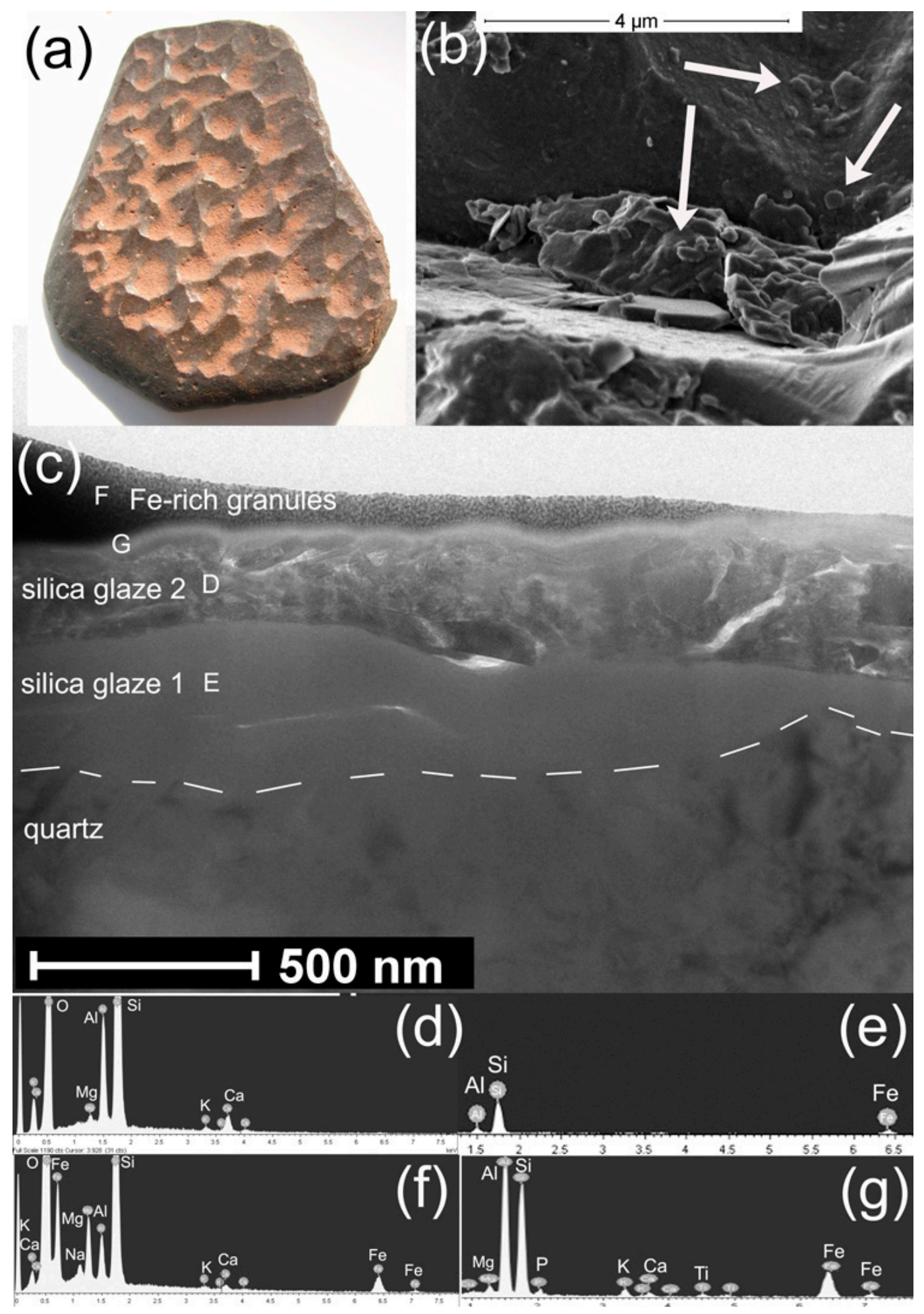

Figure 5. Complex series of rock coatings formed on the underside of desert pavement cobble in Beacon Valley. (a) The cobble underside has a light orange coloration. (b) SE image showing patches of the rock coating formed on quartz. (c) FIB-EM section through a rock coating patch, revealing a sequence of rock coatings on top of the unaltered quartz. There are two silica glaze textures, designated 1 and 2, where Locations D and E correspond with the EDX spectra (d) and (e). There is a transition between Silica Glaze 2 and the Fe-rich granules, identified by $G$ with the corresponding EDX analysis (g). (f) A typical EDX spectra of the uppermost layer with granular textures. 


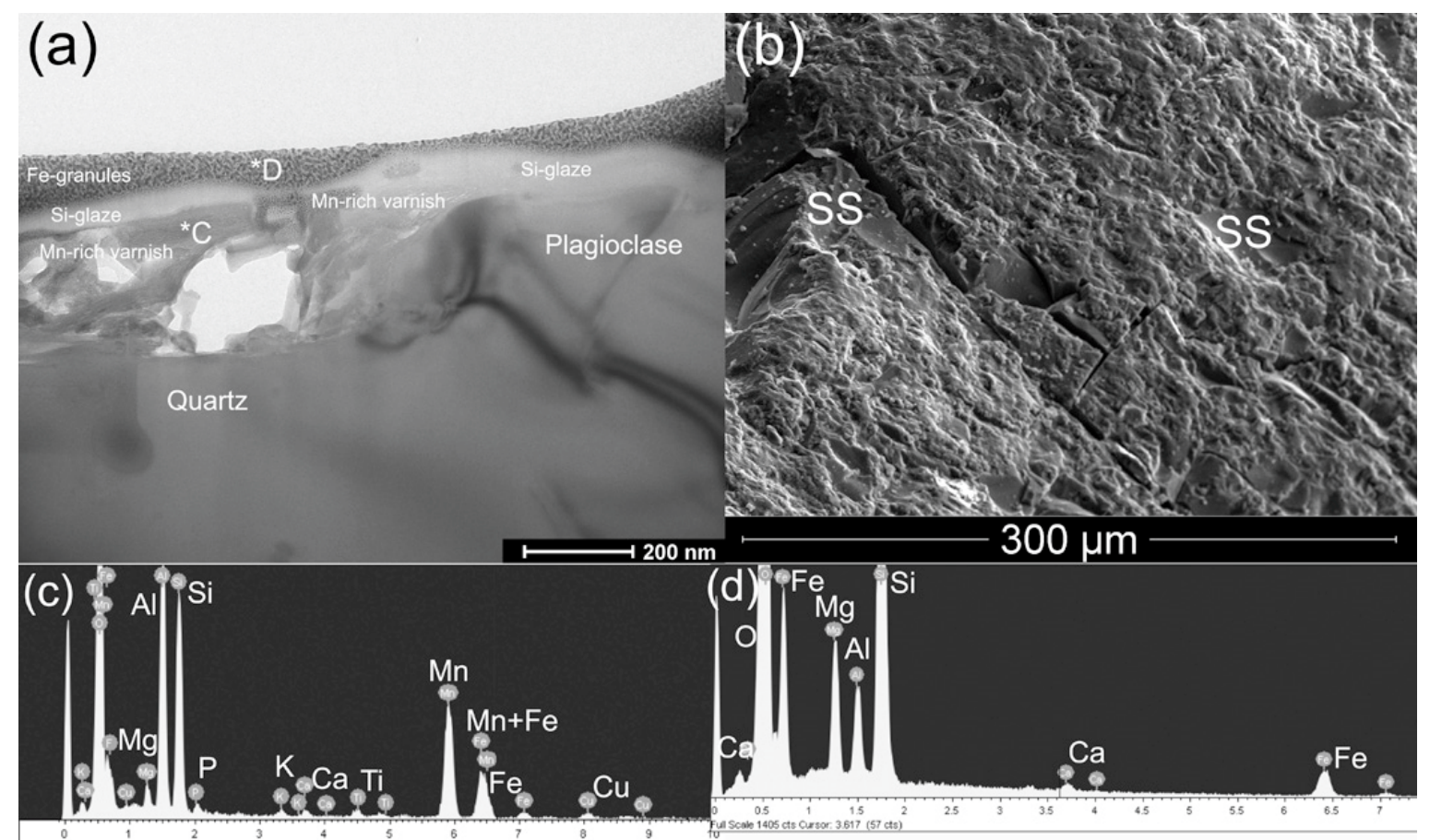

Figure 6. Complex series of rock coatings formed on the top side of desert pavement cobble in Beacon Valley. (a) FIB-EM section through a rock coating patch, revealing a sequence of rock coatings on plagioclase and quartz. The base of the rock coating consists of Mn-rich varnish, followed by silica glaze. On top of the different rock coatings and rock material is a coating of Fe granules. (b) SE image of what the surface of the Fe granules look like. A few uncoated areas of sandstone quartz occur (identified by SS), but the rest of the surface is coated with Fe-rich granules that have a lamellate texture. (c) EDS analysis of the Mn-rich varnish acquired at the asterisk next to the letter C in image (a). (d) EDS analysis of the Fe granules acquired at the asterisk next to the letter D in image (a).

Many iron films accrete on rock surfaces in, for example, Antarctic [96] and arctic [31] settings. Samples from Beacon Valley, Ross Desert, reveal a nanoscale texture of iron granules not seen previously (Figures 2a, 5c and 6a). This granular texture can be produced as an artifact of sample preparation, but we are confident that this is not the case. In SE views, the iron granules occur in depressions on the underside of desert pavement cobbles (Figure 5b) and also as more continuous coatings on the top surface of the pavement cobble (Figure 6b). Additionally, these iron granules occur in different samples regardless of how they were prepared. The EDX composition of the iron granules resembles iron films on the underside of warm desert pavement clasts with higher peaks associated with clays $(\mathrm{Mg}, \mathrm{Al}$, and $\mathrm{Si}$ ) compared with the iron hydroxides, along with minor amounts of $\mathrm{Na}, \mathrm{K}$, and $\mathrm{Ca}$ (Figures $5 \mathrm{f}$ and $6 \mathrm{~d}$ ).

Beacon Valley samples in a subaerial setting also contained a layer of Mn-rich varnish that formed the bottom layer of the observed rock coating sequence (Figures 2a and 6a). The Mn-rich varnish formed on top of the quartz and was then covered by silica glaze. Its elemental composition contained much more Mn than is typical for warm arid varnish (Figure 6c). Otherwise, the EDX spectra were similar with strong $\mathrm{Al}$ and Si peaks, as well as minor elements including $\mathrm{Mg}, \mathrm{P}, \mathrm{K}, \mathrm{Ca}, \mathrm{Ti}, \mathrm{Fe}$, and $\mathrm{Cu}$.

\subsection{Mn-Rich Bacteria Casts}

We found fossilized evidence of budding bacteria within cold climate rock varnishes. Rock varnish formed on a morainal boulder on the edge of a Greenland outlet glacier containing micron-scale casts of bacteria (Figure 7a). When viewed at the highest resolution with a BSE detector, the forms resolved as bacteria undergoing budding (Figure $7 \mathrm{~b}$ ), where the inside of the cells consists of carbon and oxygen (Figure 7c), while the casts on the outside of the cells had EDX spectra similar to those of warm desert 
rock varnish (Figure 7d), with the exception of a particularly high sulfur peak. The Mn-rich casts appeared to have a fibrous texture.

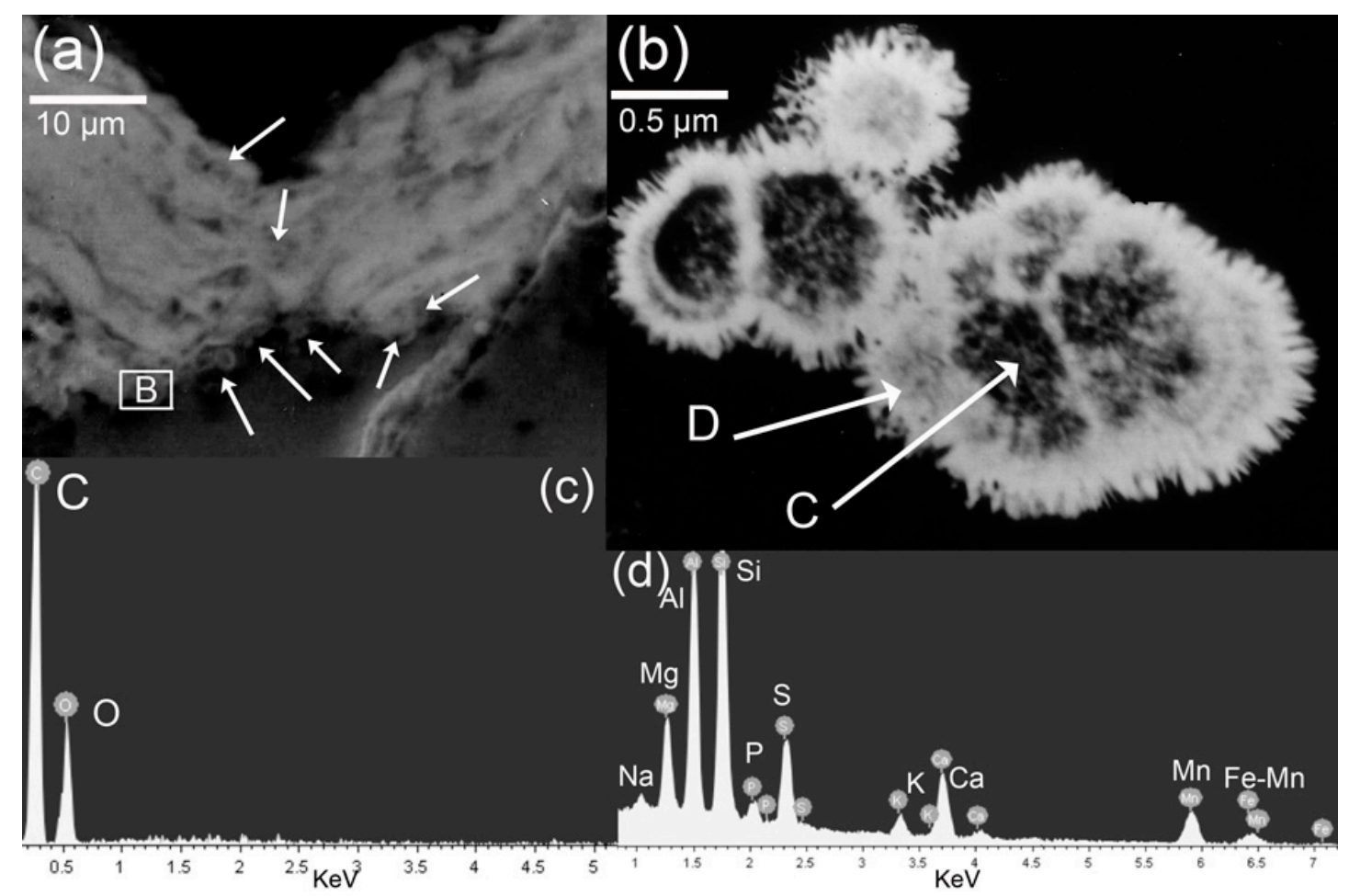

Figure 7. Mn-rich casts of budding bacteria observed within rock varnish collected from a millimeter-scale depression on a meter-sized boulder on the edge of a Greenland outlet glacier. (a) BSE image of varnish formed on quartz, where the arrows identify bacteria forms. The white box is a B in the middle identifies the location of image (b) that is a BSE close-up image of bacterial casts, caught in the act of starting to bud. Budding bacteria reproduce by developing buds, and this appeared to be taking place when the bacteria were fossilized by Mn encrustation. (c) EDX analysis of the center of one of the bacteria (identified by the letter $C$ in image $b$ ) indicates only an organic composition with carbon and oxygen. (d) EDX analysis of the outer cast of the same bacteria (identified by the letter D in image (b)) has a composition similar to rock varnish found in other environmental settings, with the exception of a stronger sulfur peak than is typical.

Rock varnish on a Mt. Van Valkenburg sample has a BSE micron-scale textural appearance (Figure 8a), similar to other observations of microstromatolitic textures in rock varnishes found in warm arid settings [102] and varnishes in humid temperate regions [103]. Upon investigation with higher resolution BSE, the laminated texture resolved into micron-scale bacteria-sized forms with a bright (high Z) atomic number. EDX analyses of these forms showed much higher concentrations of Mn (Figure 8e) than the adjacent varnish material (Figure 8f). A light treatment of the polished surface with HF to remove most of the clay minerals allowed the texture of the bacterial forms to emerge with greater clarity (Figure 8c). These forms appear to be broken segments of what could be the hyphae of budding bacteria. Certainly, the scale of these segments is appropriate for the Mn-rich casts of pieces of budding bacteria hyphae. 

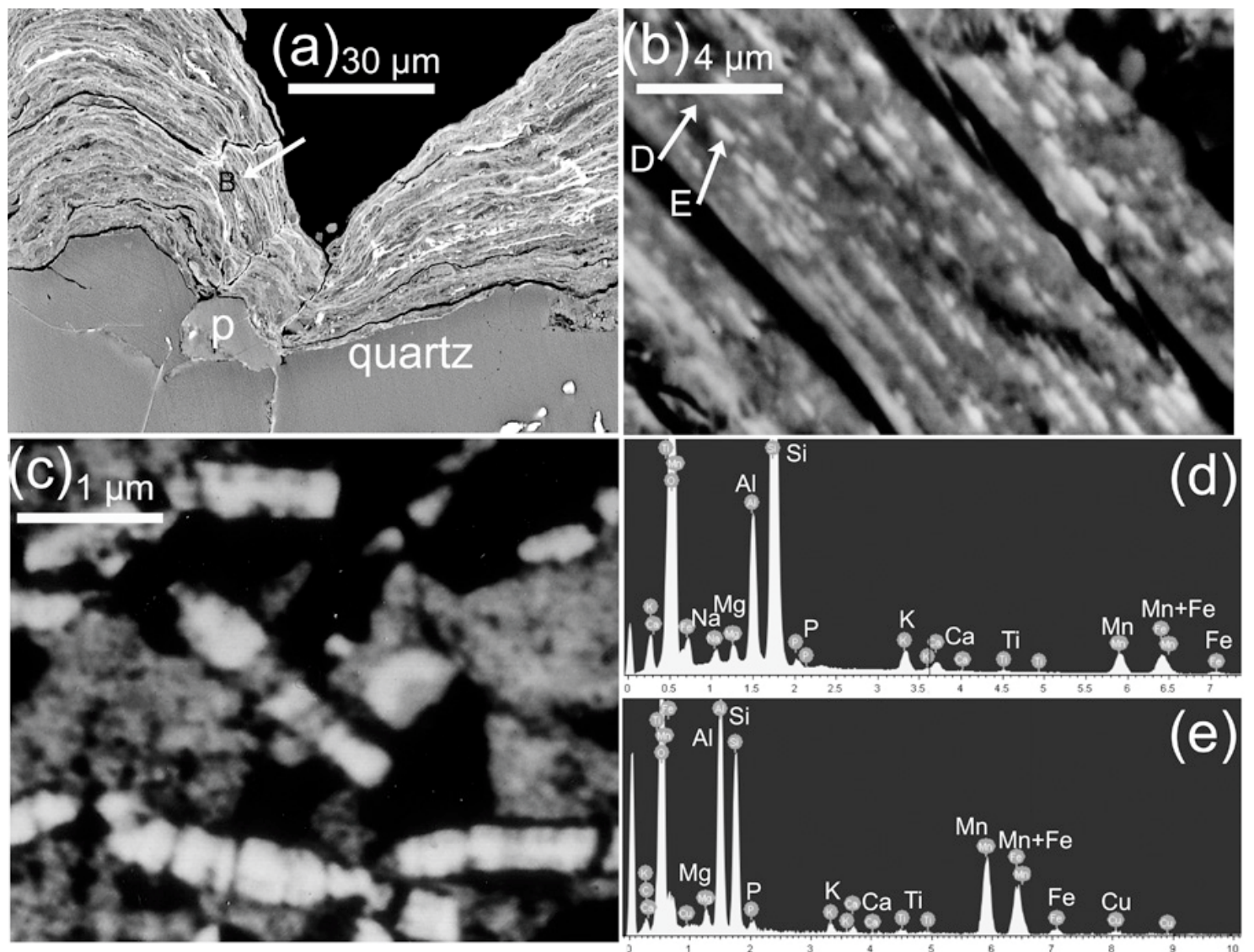

Figure 8. Manganese-rich rock varnish from Mt Van Valkenburg includes Mn-rich casts of bacteria inside varnish laminations. (a) BSE image of laminated varnish on top of quartz (also with plagioclase, p). The white arrow points to the letter B, which identifies the location of image (b), which is a BSE image showing dozens of bacterial casts. (c) Light HF treatment to partially dissolve clays resolves the bacterial casts as segments of budding bacterial casts. Locations of EDX analyses (d) and (e) are identified by the D/E arrows in image (b). EDX analysis (d) is typical of the varnish surrounding the bacteria cast, while (e) is typical of the Mn-rich cast with strong $\mathrm{Mn} \mathrm{K} \alpha$ and $\mathrm{Mn} \mathrm{K} \beta$ peaks.

The importance of scale in interpreting Antarctic rock varnish can be emphasized through Figure 9 from Beacon Valley. The surface of the sample (Figure 9a) appears dark like any Mn-rich rock varnish. In a BSE image of the polished cross section, the varnish appears laminated and about $20 \mu \mathrm{m}$ thick (Figure 9b) with bacteria-size forms on the surface (indicated by the letter $C$ in Figure $9 b$ ). At the nanoscale, bacteria resolves into a granular texture (Figure 9c) that consists of equal amounts of $\mathrm{Mn}$ and clays ( $\mathrm{Al}$ and $\mathrm{Si}$ ) with minor amounts of $\mathrm{Mg}, \mathrm{P}, \mathrm{K}, \mathrm{Ca}, \mathrm{Ba}, \mathrm{Fe}$, and $\mathrm{Cu}$ (Figure 9d). 


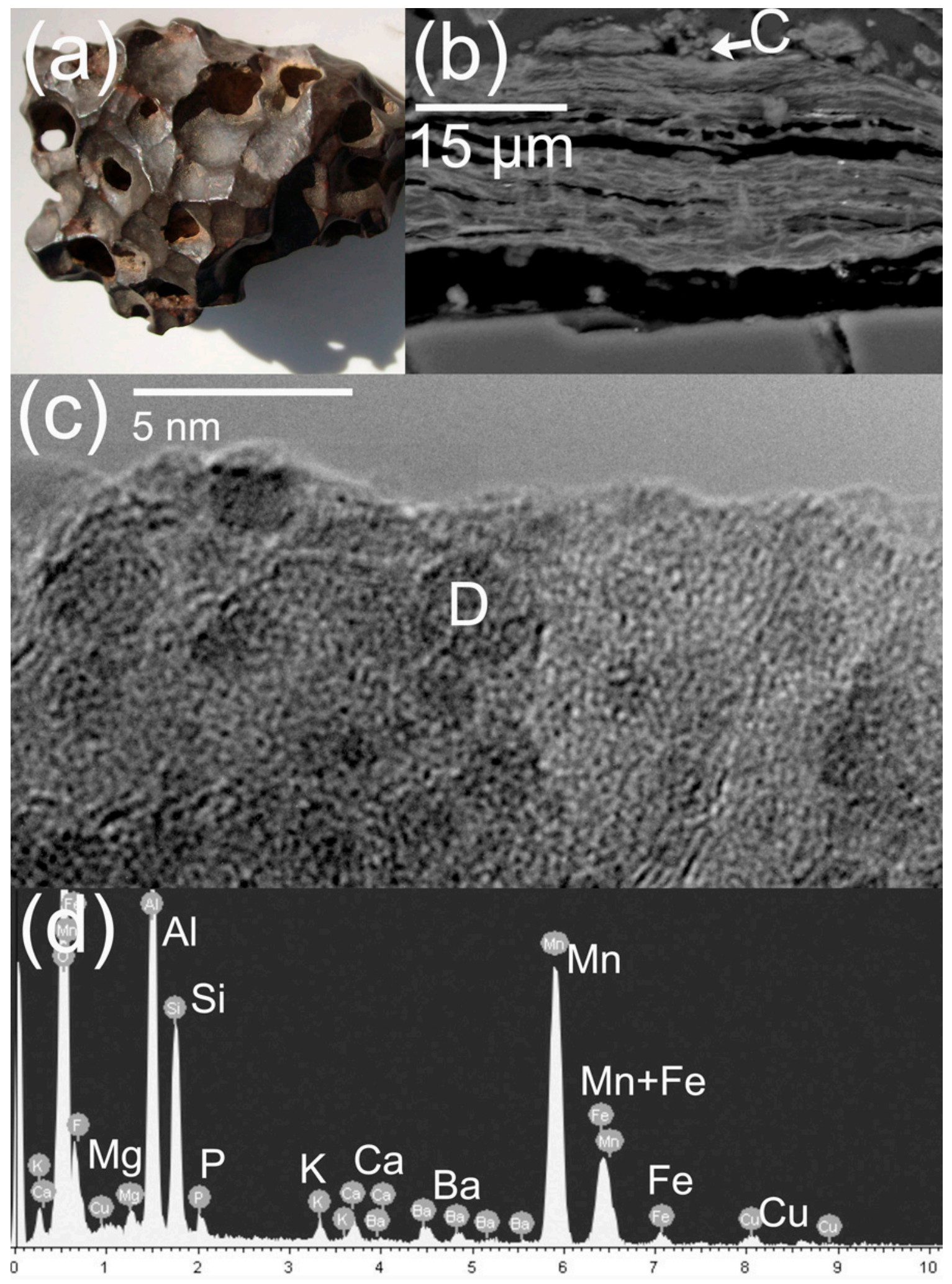

Figure 9. Antarctic rock varnish from Beacon Valley at vastly different scales. (a) Photograph of a $10 \mathrm{~cm}$ cobble from Beacon Valley. (b) BSE image of a pocket of rock varnish from one of the rock-surface depressions seen in image (a). (c) HRTEM image of the cast of bacteria located at the letter C in image (b). The granular nodules with a diameter of about $2 \mathrm{~nm}$ derive from ongoing dissolution of bacteria cell walls, where the letter D indicates the location of the EDX analysis (d). Note that the texture to the right of letter $\mathrm{D}$ has lineaments that are from clay mineral structures altered by Mn-rich granule precipitation. Also note very strong $\mathrm{Mn} \mathrm{K} \alpha$ and $\mathrm{Mn} \mathrm{K} \beta$ peaks in (d). 


\subsection{Anthropogenic Geochemical Impacts on Cold-Climate Rock Surfaces}

Human alteration of rock surfaces in cold climates occurred in some settings that are obviously anthropogenic, such as acid mine drainage water. Other geochemical changes to cold-climate settings were a result of anthropogenic changes such as removing vegetation that in turn changes the geochemistry of rock surfaces or physically disturbs the rock surfaces associated with yak animal husbandry. Still another observed effect resulted from lead air pollution distant from cold-climate settings. This section explores each of these anthropogenic influences to cold region rock surfaces in turn.

\subsubsection{Acid Mine Drainages}

An abandoned titanium mine at the margin of the Palisades Glacier [104] is the source of acidified drainage water with measured $\mathrm{pH}$ values ranging from 2.4 to 3.5. Where this water flows over rocks, they are coated with an orange iron film. The iron film consists mostly of bacteria-sized forms, about a micron in diameter, all agglomerated together (Figure 10a) along with silica glaze that appears to be filling void space. EDX analyses of the bacteria forms reveal a composition that is more than $50 \%$ elements found in clay minerals $(\mathrm{Mg}, \mathrm{Al}$, and $\mathrm{Si})$, with the second largest component being iron. Minor elements include $\mathrm{K}, \mathrm{Ti}, \mathrm{Cu}$, and $\mathrm{Zr}$ (Figure 10b).

\subsubsection{Coatings Altered by Human Activities in the Khumbu of Nepal}

Figure 11 illustrates a common scene in the Khumbu of Nepal, where glacial stone fences made of outwash cobbles are part of yak animal husbandry and other activities. The building of such stone structures modifies rock coatings that originally developed on the stones, for example, placing rock varnish developed in a subaeral environment upside down-burying the varnish in the ground. The result is a clay coating formed over the varnish (Figure 11a). Sherpa combined yak manure with some soil material and put these yak patties on walls to dry as fuel. Upon peeling these fuel pellets off stone walls, some material is left behind-material that then lithifies and results in a clay film mixed with yak manure (Figure 11c). Yaks themselves modify rock coatings by physically stepping on them and, in the case of Figure 11b, detaching the original rock varnish coating from the stone.

Vegetation change in the Khumbu of Nepal alters the biological environment stone surfaces that used to be under a coniferous cover. Removing the acidic coniferous leaf litter increases the $\mathrm{pH}$ of rock surfaces. Thus, black fungi that used to thrive under conifers are being replaced by silica glaze. Figure 12a presents one example of silica glaze entombing the desiccated remains of black fungi.

Another aspect of vegetation change immediately adjacent to the Ngozumpa glacier involves the removal of moss. Small melt water streams next to the till used to support extensive areas of moss. However, removal of the moss for fuel changed the chemistry of the small streams from acidic to near neutral. $\mathrm{pH}$ measurements next to remnant areas of moss had $\mathrm{pH}$ values ranging from 3 to 4 , but $\mathrm{pH}$ measurements where moss had been removed were between 6.5 and 7.5. The change in geochemistry resulted in a change in rock coating development (Figure 12b). Iron films first formed as a result of the acidic water, including the presence of casts of iron bacterial. However, the change in $\mathrm{pH}$ resulted in the accumulation of silica glaze over the iron films. 


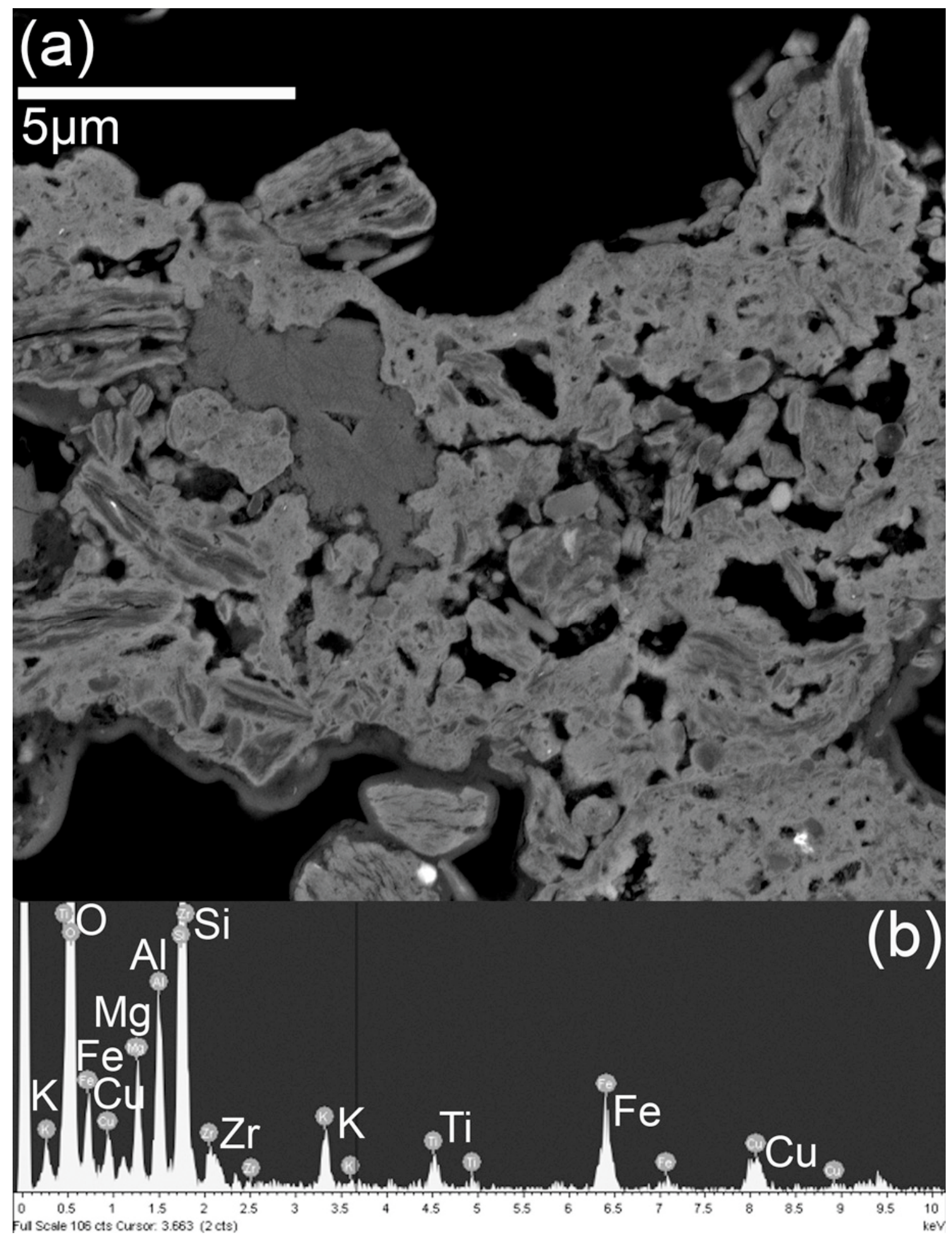

Figure 10. Iron film rock coating that developed on quartz in the drainage leading out of a titanium mine near the Palisades Glacier, Sierra Nevada, California. (a) BSE image where the brighter material has a granular texture where granules are 1 micron in scale or the size of bacteria. The darker material is silica glaze. (b) EDX analysis of a typical bacteria-sized granule. 


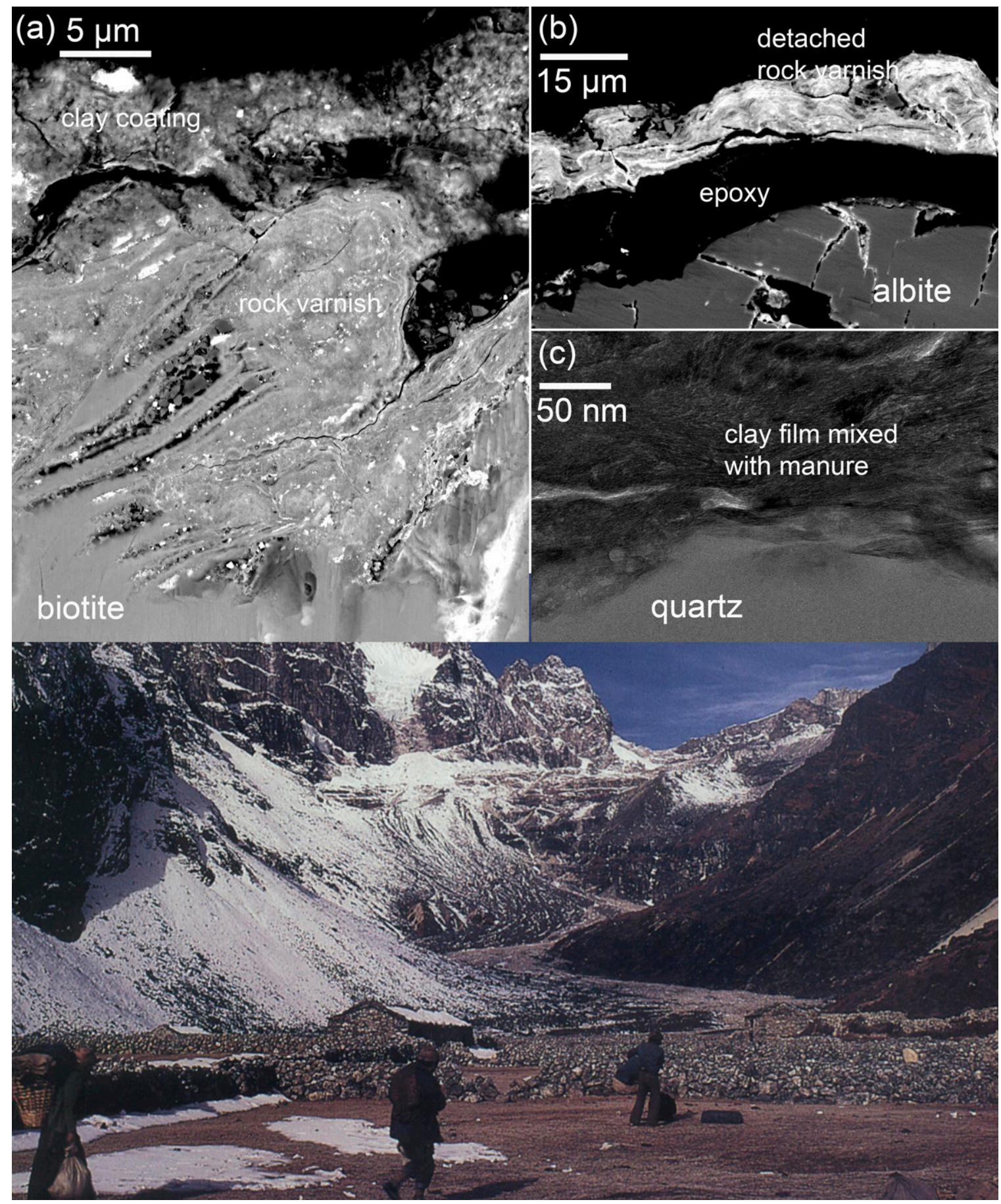

Figure 11. Rock coating alteration as a result of yak animal husbandry adjacent to the Ngozumpa glacier, Nepal. (a) BSE image of a glacial outwash cobble, coated with rock varnish, placed in the ground as a result of building a stone wall. A clay coating formed over the varnish. (b) A glacial moraine small boulder was kicked by a yak, resulting in spalling of the rock surface. Placement of epoxy over the edge of the spall preserved the spatial relationship, preserving the ability to see in this BSE image a rock varnish coating that was physically detached from the rock. (c) Yak manure combined with some soil material dried on stone walls; removal leaves behind a lithified residue of a new artificial rock coating of a clay film are mixed with manure, as seen in this HRTEM image. 


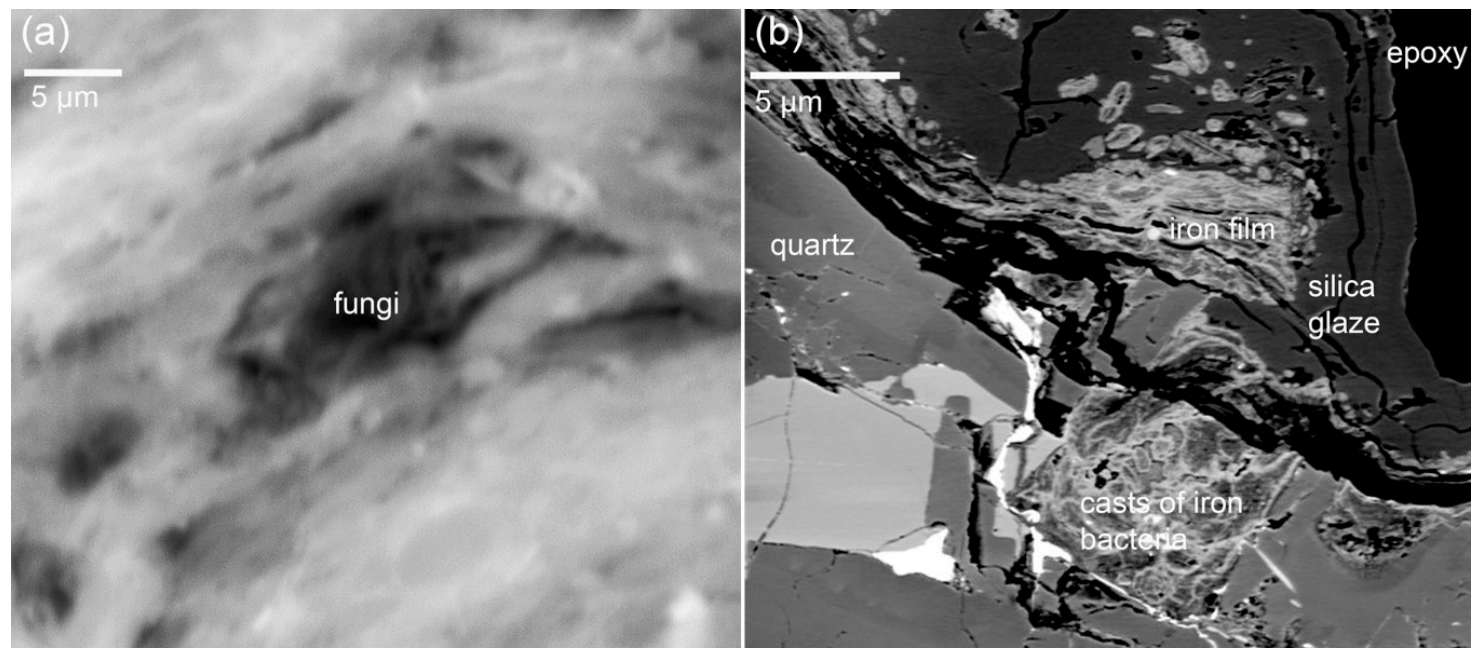

Figure 12. Alteration of rock coatings as a result of vegetation change in the Khumbu region of Nepal. (a) Secondary electron view of the surface of a rock that used to be underneath a conifer forest. This view shows the desiccated remains of black fungi that is surrounded by silica glaze-where the silica glaze cannot form naturally under the decaying pine needles. However, with deforestation, the less acidic $\mathrm{pH}$ allows silica glaze to accumulate. (b) BSE image of a cross section of rock coatings on a cobble in a stream bed next to the Ngozumpa glacier. At first, iron films and casts of iron bacteria coated rock surfaces exposed to acidic waters of moss-rich areas. Removal of the moss changed the water to a less acidic $\mathrm{pH}$ and this led to the deposition of silica glaze over the iron film.

\subsubsection{Lead Contamination of Rock Surface Coatings}

A boulder on the side of a Greenland outlet glacier (Figure 13a) hosts rock varnish accumulations in millimeter-scale rock-surface depressions (Figure 13b). WDS electron microprobe analyses in a transect from the base of the varnish to the surface reveal lead contamination in the upper micron of the rock varnish. The WDS analyses in percent $\mathrm{PbO}$ had a detection limit of $0.03 \%$. For most of the varnish, a typical condition of $<0.03 \% \mathrm{PbO}$ existed, but the surface-most micron had a lead spike reaching $0.19 \%$. FIB-EM HRTEM imagery of the location of the microprobe measurement (Figure 13c) reveals that the lead is not evenly dispersed. Instead, EDX analyses revealed identifiable PbO peaks at he darkest (least electron transparent) materials in Figure 13c.

\section{Discussion}

This discussion section links results presented in Figures 1-13 to prior scholarship on cold climate rock-surface processes. The results clearly confirm findings by Rapp [23], Hall [14,24-26], Dixon [27-35], Thorn [36-38], their collaborators, and others [40-47,105-107] on the importance of chemical processes in cold climate geomorphic settings. However, Figures 1-13 also reveal new details of rock-surface chemical 1 processes at the nanoscale that, we hope, opens the eyes of cold-climate researchers who only perceive "minimal chemical weathering" [39] when they see bare rock (e.g., Figures 1, 11 and 13a). Whereas many geoscientists only see the visual scale evidence of angular fractures that rest at the core of geomorphic weakness [1-4], the hope is that they stop and think about the nanoscale and micron-scale observations presented here that consistently reveal a persistent story of chemical processes decaying and of coating rock surfaces. 


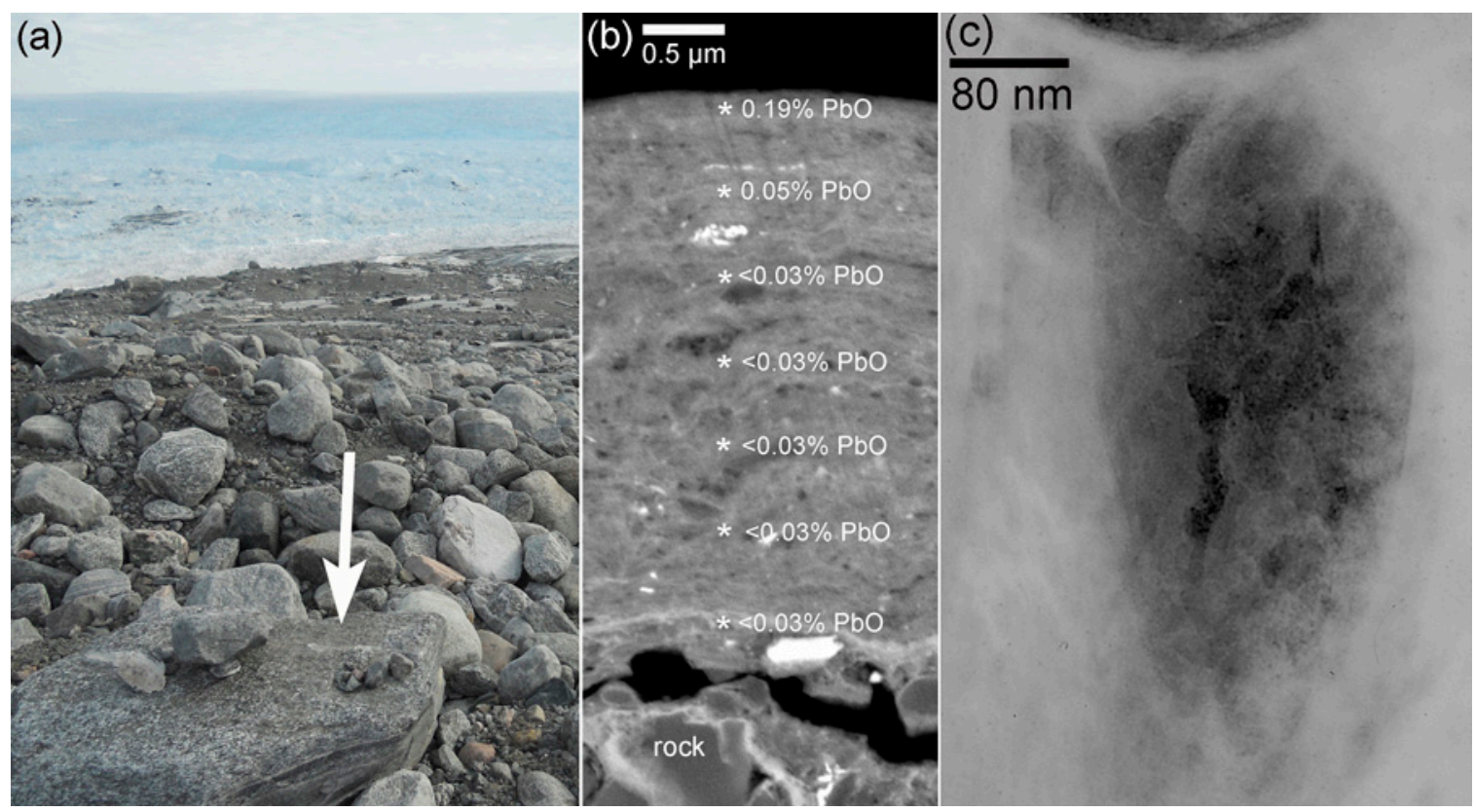

Figure 13. Anthropogenic lead emissions contaminate the surfaces of cold climate rocks even in areas distant from emission sources. (a) Gneissic boulder on the edge of a Greenland outlet glacier, where the white arrow indicates the sampling location of a pocket of Mn-rich rock varnish. (b) Mn-rich rock varnish identifying the locations of WDS microprobe analyses for lead where $<0.03 \% \mathrm{PbO}$ is the background level. Note that the surface-most analysis contains $0.19 \% \mathrm{PbO}$. (c) FIB-EM image of the location of the high lead measurement. The dark material is Mn-rich material, where the darkest zones have EDX peaks indicative of lead.

\subsection{Nanoscale Evidence of Chemical Processes Decaying Rock Surfaces}

Iron films form extensive rock coatings in Kärkevagge, Swedish Lapland [31]. In addition to accreting on rock surfaces, the iron dissolves and mobilizes into mineral and rock fractures in the underlying rock $[31,32]$. The precipitation of the iron acts as a wedging agent, breaking apart minerals into silt and clay-sized particles (Figure 1). Thus, the physical rock decay process of iron cracking starts with chemical processes. In the case of the Greenland observations (Figure 1), the source of the iron derives from the chemical decay of iron minerals such as magnetite and the dissolution of rock varnish.

Pope used HRTEM to study quartz decay in dryland settings, discovering that quartz changes to an amorphous condition with crystalline defects [59] - perhaps undergoing a form of quartz hydration. Pope found that unweathered crystalline quartz is characterized by a regular lattice arrangement. However, amorphous zones tend to be disorganized along zones of structural weakness. Whereas Pope had to thin HRTEM by hand, FIB-EM (Table 2) makes the process far simpler by facilitating sample preparation.

A sample from Beacon Valley reveals what Pope observed previously [59]: amorphous quartz (Figure 2c). The zone of quartz alteration rests underneath rock coatings (Figure 2a). Amorphous zones also occur in quartz from the Khumbu region of Nepal near the Ngozumpa glacier (Figure 11c), where the amorphous zones appear to be in pockets tens of nanometers across, found underneath yak manure. In addition to quartz hydration, dissolution generates nanoscale pores (Figure $2 b$ ). Dissolution pores were also observed in andesite weathering rinds of a recent Iztaccíhuatl moraine as evidenced by intra-mineral porosity (Figure $4 a-c)$.

What is surprising and could not have been possible for Pope [59] to analyze given the instrumentation in 1995 is that quartz hydration also imports elements not native to quartz (Figure 2e) such as phosphorus (Figure $2 \mathrm{~d}, \mathrm{f}$ ). It is possible that water vapor interactions, even in the absence of liquid water [108], could influence these quartz alterations. 
Quartz alteration, whether from hydration or another process, has the effect of making surfaces rougher. Mechanical fracturing of quartz produces conchoidal fracturing with surfaces too smooth for particle adherence. In contrast, roughened surfaces facilitate adherence of aeolian particles to rock surfaces through van der Waals forces $[109,110]$. The altered quartz, mixing with undecayed quartz, creates sufficient surface roughness (Figure $3 c$ ) to promote the adherence of dust particles onto exposed free quartz in the cold, dry Akesu volcanic field, Tibetan plateau (Figure 3a).

Quartz is not the only mineral undergoing chemical decay in the studied samples. Biotite feathering in the Khumbu of Nepal occurs in concert with rock varnish remobilization (Figure 11a). As the biotite splits from hydration and iron oxidation, mobilized varnish moves down into this "weathering rind" and plugs up most of the voids generated by biotite splitting. Prior research in cold climates previously found abundant evidence for the chemical decay of a variety of minerals [78,111-116].

\subsection{Nanoscale Observations of Rock Coatings}

A variety of rock coatings formed on analyzed the cold climate samples, notably different types of silica glaze, iron films consisting of Fe-rich granules, iron films composed of casts of bacteria, rock varnish, and notably fossilized Mn-rich budding bacteria.

Silica glaze has long been noted in Antarctic samples [74,106,117], and others have previously observed intercalation of different rock coatings, namely silica glaze and sulfate crust in Victoria Land, Antarctica [74], and rock varnish and silica glaze on the Tibetan Plateau [89]. Similarly, the different rock coatings observed here have been noted in Sweden [31], Greenland [118], Iceland [119], and Antarctica [120]. Thus, observing different types of silica glaze, different types of iron film and rock varnish is not new in cold climate research.

Sulfate-rich precipitates are frequently noted in a variety of Antarctic contexts from weathering rinds to rock coatings [74,79,107], in the Swedish Lapland [121], and it has been suggested that sulfate plays a role in barium's behavior in rock varnish [122], sometimes being enriched and correlated with Mn and sometimes not being present in anything other than very minor amounts [123]. Thus, the presence of a strong S-peak in the bacterial sheath observed in Greenland (Figure 7d) should not be surprising.

The nanoscale observations of rock coatings presented here, however, did uncover aspects not previously noted in scholarship. Beacon Valley iron films maintain a granular texture (Figures 2a, $5 \mathrm{c}$ and 6a) that is not an artifact of sample preparation. The 20-70 nm diameter of the granules is much too great to be bacterial casts. However, Langworthy et al. [120] discovered that silica glaze formation on the Akesu volcanic field of the Tibetan Plateau, and perhaps elsewhere, starts as soluble Al-Si complexes $\left[\mathrm{Al}\left(\mathrm{OSi}(\mathrm{OH})_{3}\right)^{2+}\right]$ released from the weathering of phyllosilicate minerals. These Al-Si complexes are then stabilized through very gentle wetting such as frost sublimation or the movement of capillary water on rock surfaces. The iron-rich granules that are dominated by silica (Figure $5 \mathrm{f}$ ) could potentially form in a similar way, given that they have a similar diameter. If gentle wetting events are responsible, then these wetting events could explain the granules' decrease in size with depth in one sample (Figure 2a), as the granules were dissolved and then reprecipitated.

The Mn-rich casts observed in association with fossilized budding bacteria display a fibrous texture of fine spines and long bundles of hair-like manganese oxides very similar to what has been seen on the cell wall of natural microbial communities [124], culturing studies [125], and fossilized budding bacteria in varnishes non-cold-climate settings [126]. These fibrous forms could be the result of different processes, such as Mn(II) absorption [127], bacterial oxidation [126], bacterial use of Mn (IV) as extracellular respiratory electron acceptors [128], or some combination of processes.

These nanoscale observations of cold climate rock varnish are consistent with the polygenetic model of rock varnish formation where diagenesis breaks apart these cell encustrations into nanoscale granules [68] that are then remobilized and reprecipitated amongst the mixed-layer clays (e.g., Figure 9) in a process first explained by Potter ([129], pp. 174-175): 
"Deposition of the manganese and iron oxides within the clay matrix might then cement the clay layer...the hexagonal arrangement of the oxygen in either the tetrahedral or octahedral layers of the clay minerals could form a suitable template for crystallization of the layered structures of birnessite." [129]

McKeown and Post ([130], p. 712) emphasized that ongoing disequilibria continue even after the varnish formed:

"[e]ven if analysis methods are improved, the situation will remain complicated by the flexibility and great variety of Mn oxide structures. The common elements of these structures enable them to easily intergrow with and transform with one another." [130]

Thus, while budding bacteria originally enhance the Mn-Fe (Figures 7 and 8), it is the geochemical dissolution at the nanoscale and subsequent reprecipitation of oxyhydroxides in clays (Figure 9) that results in varnish formation.

The left side of Figure $9 \mathrm{c}$ shows the outer portion of the bacterial cast, while the right side of Figure $9 \mathrm{c}$ started out as clay minerals with a typical linear structure. The granular nanoscale texture seen in this FIB-EM view is typical of how bacterial casts slowly dissolve and are mobilized away from the bacterial casts. The layering typical of clay minerals in HRTEM views of varnish [67] is being broken apart by the dissolution and then the reprecipitation of the Mn-rich granules into the clays - to the point where the layered texture is mostly lost (Figure 9c). These nanoscale movements do not create instability in the varnish laminations seen at the micron scale that are stable for tens of millennia [131-133]. Scale matters and these snanoscale movements would be analogous to cars shuffling in a parking structure composed of micron-scale laminations.

An issue that sometimes arises with regard to rock varnish (or "desert varnish") is whether this rock coating is the same in warm deserts and cold climates. The clear and simple answer is yes. The phenomenon is the same, and different environments of formation show a similar variability outlined in detail elsewhere $[96,120]$. A good part of the confusion with regard to "varnish" in Antarctica is that several researchers who published early papers on the topic misnamed the rock decay features under investigation $[74,134,135]$.

Several prior studies lack the direct observation of bacteria and other microorganisms in weathering rinds and rock coatings in Antarctica $[75,77,79,134]$. Thus, the natural question is why we have observed bacteria (Figures 7-10) where others have not. A number of possibilities emerge, including improvements in sample preparation techniques and microscopy such as FIB-EM (Table 2) that allow better preservation of delicate features as well as real spatial variability in the presence of preserved microorganisms. One issue pertaining to our observations of bacteria involves potential sample contamination; we think that the chance of contamination is truly remote to non-existent because we only examined material entombed naturally in rock coatings. None of the observations reported here pertain to surfaces that could have been contaminated in sample handling and transport.

\subsection{Anthropogenic Geochemical Impacts on Cold-Climate Rock Surfaces}

In contrast to the granular iron films of Beacon Valley, those observed in high alpine acid-mine drainage (Figure 10a) consist of bacteria-sized forms that agglomerated together. These forms appear similar to those observed in natural microbial communities [124] and resemble iron secreted on the cell walls of bacteria living in acid waters [136]. The high concentrations of titanium and zirconium could be explained by the ability of the iron to scavenge heavy metals [137].

Acidification of temperate rock surfaces results in the dissolution of rock varnish as exemplified by acid fog in Southern California [138] and industrial emissions in Western Australia [139]. In contrast, the reduction of acidity in the Khumbu region of Nepal from deforestation of acid-producing plants had the opposite effect on rock coatings. Fungi that had been active in mineral dissolution became encased in silica glaze (Figure 12a), and iron film that formed in an acidic drainage of a sphagnum bog became encased in silica glaze after the sphagnum was removed for fuel (Figure 12b). 
The first study of lead in relation to rock varnish occurred with respect to the Earthen figure (or geolyph) called the Bouse Fisherman. This is the figure of a human holding a spear with a quartz tips ([96], p. 139):

"Lead accumulates in rock varnishes and dust films on desert surfaces. Electron microprobe profiles reveal that lead is a contaminant in the uppermost surfaces of rock varnishes, but these concentrations drop to background levels below the very surface of natural rock coatings that have formed since lead additives were introduced into gasoline in 1922." (Dorn [96], p. 139)

This observation now has extensive replication [97,98,140-145]. Twentieth-century industrial activities spread lead and other elemental pollutant around the globe, even in areas distant from major lead-pollution sources [146-148]. Thus, the spike in lead on the surface of varnish next to a Greenland outlet glacier (Figure 13) should not be surprising; what is new is that the lead appears to be concentrated in nanoscale granules (Figure 13c). These TEM observations appear similar to the bacterial accumulation of lead in temperate settings [149]. The concentration of lead could also be a product of the affinity of lead for biogenic manganese oxides [150] that have a granular appearance (Figure 9c).

\section{Conclusions}

Every sample from alpine, arctic, and Antarctic cold climate sites studied here reveals the dominance of nanoscale chemical rock-surface processes in cold climates. Many studied samples also display evidence for the importance of microorganisms in the formation of rock varnish as well as iron film rock coatings. We hope that some of the findings here could assist in interpreting surficial processes on Mars so as to avoid the early history of ignoring chemical rock decay in terrestrial cold climates. While the visual evidence of "fresh rock" may fool some geoscientists some of the time, the ubiquitous evidence of chemical rock decay and chemical processes influencing rock coatings leads to the inevitable conclusion that it is "chemical weathering" that truly dominates rock decay in cold climates.

Author Contributions: D.H.K. contributed microscope imagery and analyses, discussed extensively with R.I.D. the interpretation of the imagery, and co-wrote the first part of the paper before his death. R.I.D. completed the manuscript.

Funding: This research received no external funding.

Acknowledgments: Two anonymous reviewers made wonderful suggestions, and I am delighted to thank them on behalf of Dave Krinsley and myself. Dave and I thank the talented CAMCOR facility experts in sample preparation and microscopy, notably J. Razink, R. Fisher, J. Ditto, and K. Langworthy. We thank the geosciences collection at Texas Tech University for samples from Mt. Van Valkenburg and Beacon Valley, Ross Desert, Antarctica, J.G. Bockheim for a sample from Beacon Valley, T.L. Liu for samples from the Akesu volcanic field, Tibet, and Barbara Murphy for the Greenland samples.

Conflicts of Interest: The authors declare no conflict of interest.

\section{References}

1. Molnar, P.; Anderson, R.S.; Andersson, S.P. Tectonics, fracturing of rock, and erosion. J. Geophys. Res. Earth Surf. 2007, 112. [CrossRef]

2. Scott, D.N.; Wohl, E.E. Bedrock fracture influences on geomorphic process and form across process domains and scales. Earth Surf. Process. Landf. 2018, 1-19. [CrossRef]

3. Eppes, M.C.; Hancock, G.S.; Chen, X.; Arey, J.; Dewers, T.; Huettenmoser, J.; Kiessling, S.; Moser, F.; Tannu, N.; Weiserbs, B.; et al. Rates of subcritical cracking and long-term rock erosion. Geology 2018, 46, 951-954. [CrossRef]

4. Scheidegger, A.E. Surface joint systems, tectonic stresses and geomorphology: A reconciliation of conflicting observations. Geomorphology 2001, 38, 213-219. [CrossRef] 
5. Hobbs, D.W. The formation of tension joints in sedimentary rocks: An explanation. Geol. Mag. 1967, 104, 550-556. [CrossRef]

6. Ehlen, J. Some effects of weathering on joints in granitic rocks. Catena 2002, 49, 91-109. [CrossRef]

7. Engelder, T. Joints and shear fractures in rock. In Fracture Mechanics of Rock; Atkinson, B., Ed.; Academic Press: Orlando, FL, USA, 1987; pp. 27-69.

8. Schultz, R.A. Growth of geologic fractures into large-strain populations: Review of nomenclature, subcritical crack growth, and some implications for rock engineering. Int. J. Rock Mech. Min. Sci. 2000, 37, 403-411. [CrossRef]

9. Twidale, C.R.; Bourne, J.A. Bornhardts. Z. Geomorphol. Suppl. 1978, 31, 111-137.

10. St Clair, J.; Moon, S.; Holbrook, W.S.; Perron, J.T.; Riebe, C.S.; Martel, S.J.; Carr, B.; Harman, C.; Singha, K.; deB Richter, D. Geophysical imaging reveals topographic stress control of bedrock weathering. Science 2015, 350, 534-538. [CrossRef]

11. Eyles, N.; Arnaud, E.; Scheidegger, A.E.; Eyles, C.H. Bedrock jointing and geomorphology in southwestern ontario, canada: An example of tectonic predesign. Geomorphology 1997, 19, 17-34. [CrossRef]

12. Hall, K.; Thorn, C.E.; Sumner, A. On the persistence of 'weathering'. Geomorphology 2012, 149-150, 1-10. [CrossRef]

13. Hall, K. Perceptions of rock weathering in cold regions: A discussion on space and time attributes of scale. Géomorphol. Relief Processus Environ. 2006, 3, 187-196. [CrossRef]

14. Hall, K.; Thorn, C. The historical legacy of spatial scales in cold region weathering: Misrepresentation and resulting misdirection. Geomorphology 2011, 130, 83-90. [CrossRef]

15. Hall, K. The role of thermal stress fatigue in the breakdown of rock in cold regions. Geomorphology 1999, 31, 47-63. [CrossRef]

16. Hall, K.; André, M.F. New insights into rock weathering from high-frequency rock temperature data: An antarctic study of weathering by thermal stress. Geomorphology 2001, 41, 23-35. [CrossRef]

17. Hall, K.; André, M.F. Rock thermal data at the grain scale: Applicability to granular disintegration in cold environments. Earth Surf. Process. Landf. 2003, 28, 823-836. [CrossRef]

18. Walder, J.S.; Hallet, B. The physical basis of frost weathering: Toward a more fundamental and unified perspective. Arct. Alp. Res. 1986, 18, 27-32. [CrossRef]

19. Van Vliet-Lanoë, B.; Fox, C.A. Frost action. In Interpretation of Micromorphological Features of Soils and Regoliths; Stoops, G., Marcelino, V., Mees, F., Eds.; Elsevier: Amsterdam, The Netherlands, 2018; pp. 575-603.

20. Hobbs, W.H. Earth Features and Their Meaning. An Introduction to Geology for the Student and the General Reader; MacMillan: New York, NY, USA, 1919.

21. Holmes, A. Principles of Physical Geology; Ronald Press: New York, NY, USA, 1965; p. 1288.

22. McKnight, T.L. Physical Geography: A Landscape Appreciation; Prentice-Hall: Englewood Cliffs, NJ, USA, 1993.

23. Rapp, A. Recent development of mountain slopes in karkevagge and surroundings, northern scandinavia. Geogr. Ann. 1960, 42A, 71-201.

24. Hall, K. Enhanced bedrock weathering in association with late-lying snowpaches: Evidence from livingston island, antarctica. Earth Surf. Process. Landf. 1993, 18, 121-129. [CrossRef]

25. Hall, K.; André, M.-F. Temperature observations in antarctic tafoni: Implications for weathering, biological colonization, and tafoni formation. Antarct. Sci. 2006, 18, 377-384. [CrossRef]

26. Hall, K.; Otte, W. A note on biological weathering on nunataks of the juneau icefield, alaska. Permafr. Periglac. Process. 1990, 1, 189-196. [CrossRef]

27. Dixon, J.C. Solute movement on hillslopes in the alpine environment of the colorado front range. In Hillslope Processes; Abrahams, A.D., Ed.; Allen and Unwin: London, UK, 1986; pp. 139-159.

28. Dixon, J.C. Chemical weathering in cold climates. In Treatise on Geomorphology, Volume 4; Pope, G., Ed.; Academic Press: San Diego, CA, USA, 2013; pp. 245-257.

29. Dixon, J.C.; Thorn, C.E. Chemical weathering and landscape development in alpine environments. Geomorphology 2005, 67, 127-145. [CrossRef]

30. Dixon, J.C.; Thorn, C.E.; Darmody, R.G. Chemical weathering processes on the vantage peak nunatak, juneau icefield, southern alaska. Phys. Geogr. 1984, 5, 111-131. [CrossRef]

31. Dixon, J.C.; Thorn, C.E.; Darmody, R.G.; Campbell, S.W. Weathering rinds and rock coatings from an arctic alpine environment, northern scandinavia. Geol. Soc. Am. Bull. 2002, 114, 226-238. [CrossRef] 
32. Pope, G.; Dorn, R.I.; Dixon, J. A new conceptual model for understanding geographical variations in weathering. Ann. Assoc. Am. Geogr. 1995, 85, 38-64.

33. Campbell, S.W.; Dixon, J.C.; Darmody, R.G.; Thorn, C.E. Spatial variation of early season surface water chemistry in karkevagge, swedish lapland. Geogr. Ann. A 2001, 83, 169-178. [CrossRef]

34. Campbell, S.W.; Dixon, J.C.; Thorn, C.E.; Darmody, R.G. Chemical denudation rates in karkevagge, swedish lapland. Geogr. Ann. A 2002, 84, 179-185. [CrossRef]

35. Dixon, J.C. Stone pavements, lag deposits, and contemporary landscape evolution. In Dynamic Mars: Recent and Current Evolution of the Red Planet; Soare, R.J., Conway, S.J., Clifford, S.M., Eds.; Elsevier: Amsterdam, The Netherlands, 2018; pp. 387-410.

36. Thorn, C.E.; Darmody, R.G.; Dixon, J.C.; Schlyter, P. The chemical weathering regime of karkevagge, arctic-alpine sweden. Geomorphology 2001, 41, 37-52. [CrossRef]

37. Thorn, C.E.; Dixon, J.C.; Darmody, R.G.; Allan, C.E. Ten years (1994-2004) of "potential" weathering in kärkevagge, swedish lapland. Catena 2006, 65, 272-278. [CrossRef]

38. Thorn, C.E.; Dixon, J.C.; Darmody, R.G.; Rissing, J.M. Weathering trends in fine debris beneath a snow patch, niwot ridge, front range, colorado. Phys. Geogr. 1989, 10, 307-321. [CrossRef]

39. Marrero, S.M.; Hein, A.S.; Naylor, M.; Attal, M.; Shanks, R.; Winter, K.; Woodward, J.; Dunning, S.; Westoby, M.; Sugden, D. Controls on subaerial erosion rates in antarctica. Earth Planet. Sci. Lett. 2018, 501, 56-66. [CrossRef]

40. Kanamaru, T.; Suganuma, Y.; Oiwane, H.; Miura, H.; Miura, M.; Okuno, J.I.; Hayakawa, H. The weathering of granitic rocks in a hyper-arid and hypothermal environment: A case study from the sør-rondane mountains, east antarctica. Geomorphology 2018, 317, 62-74. [CrossRef]

41. Heindel, R.C.; Lyons, W.B.; Welch, S.A.; Spickard, A.M.; Virginia, R.A. Biogeochemical weathering of soil apatite grains in the mcmurdo dry valleys, antarctica. Geoderma 2018, 320, 136-145. [CrossRef]

42. Salvatore, M.; Truitt, K.; Roszell, K.; Lanza, N.; Rampe, E.; Mangold, N.; Dehouck, E.; Wiens, R.; Clegg, S. Investigating the role of anhydrous oxidative weathering on sedimentary rocks in the transantarctic mountains and implications for the modern weathering of sedimentary lithologies on mars. Icarus 2019, 319, 669-684. [CrossRef]

43. Dabski, M. Application of the handysurf e-35b electronic profilometer for the study of weathering micro-relief in glacier forelands in se iceland. Acta Geol. Pol. 2015, 65, 389-401. [CrossRef]

44. Joo, Y.J.; Soreghan, A.M.; Madden, M.E.E.; Soreghan, G.S. Quantification of particle shape by an automated image analysis system: A case study in natural sediment samples from extreme climates. Geosci. J. 2018, 22, 525-532. [CrossRef]

45. Mergelov, N.; Mueller, C.W.; Prater, I.; Shorkunov, I.; Dolgikh, A.; Zazovskaya, E.; Shishkov, V.; Krupskaya, V.; Abrosimov, K.; Cherkinsky, A.; et al. Alteration of rocks by endolithic organisms is one of the pathways for the beginning of soils on earth. Sci. Rep. 2018, 8, 3367. [CrossRef]

46. Etienne, S. The role of biological weathering in periglacial areas: A study of weathering rinds in south iceland. Geomorphology 2002, 47, 75-86. [CrossRef]

47. Etienne, S.; Dupont, J. Fungal weathering of basaltic rocks in a cold oceanic environment (iceland): Comparison between experimental and field observations. Earth Surf. Process. Landf. 2002, 27, 737-748. [CrossRef]

48. Blacker, J.J. Chemical Weathering Processes Leading to Soil Development in Arctic Glacial Forefields. Ph.D. Thesis, School of Earth and Environment, University of Leeds, Leeds, UK, 2018.

49. Hochella, M.F.; Lower, S.K.; Maurice, P.A.; Penn, R.L.; Sahai, N.; Sparks, D.L.; Twining, B.S. Nanominerals, mineral nanoparticles, and earth systems. Science 2008, 319, 1631-1635. [CrossRef]

50. Hochella, M.F. Nanoscience and technology: The next revolution in the earth sciences. Earth Planet. Sci. Lett. 2002, 203, 593-605. [CrossRef]

51. Banfield, J.F.; Eggleton, R.A. Analytical transmission electron microscope studies of plagioclase, muscovite and k-feldsapr weathering. Clay Clay Miner. 1990, 38, 77-89. [CrossRef]

52. Dorn, R.I.; Gordon, S.J.; Krinsley, D.; Langworthy, K. Nanoscale: Mineral weathering boundary. In Treatise on Geomorphology, Volume 4; Pope, G.A., Ed.; Academic Press: San Diego, CA, USA, 2013; Volume 4, pp. 44-69.

53. Benzerara, K.; Yoon, T.H.; Menguy, N.; Tyliszczak, T.; Brown, G.E. Nanoscale environments associated with bioweathering of a mg-fe-pyroxene. Proc. Natl. Acad. Sci. USA 2005, 102, 979-982. [CrossRef] [PubMed] 
54. Bonneville, S.; Smits, M.M.; Brown, A.; Harrington, J.; Leake, J.R.; Brydson, R.; Benning, L.G. Plant-driven fungal weathering: Early stages of mineral alteration at the nanometer scale. Geology 2009, 37, 615-618. [CrossRef]

55. Lower, S.K.; Hochella, M.F.; Beveridge, T.J. Bacterial recognition of mineral surfaces: Nanoscale interactions between shewanella and alpha-feooh. Science 2001, 292, 1360-1363. [CrossRef] [PubMed]

56. Gilbert, B.; Banfield, J.F. Molecular-scale processes involving nanoparticulate minerals in biogeochemical systems. In Molecular Geomicrobiology; Banfield, J.F., Cervini-Silva, J., Nealson, K.H., Eds.; Mineralogical Society of America: Washington, DC, USA, 2005; pp. 109-156.

57. Jiang, Z.; Liu, Q.; Roberts, A.P.; Barron, V.; Jorrent, J.; Zhang, Q. A new model for transformation of herrihydrite to hematite in soils and sediments. Geology 2018, 46, 987-990.

58. McMaster, T.J. Atomic force microscopy of the fungi-mineral interface: Applications in mineral dissolution, weathering and biogeochemistry. Curr. Opin. Biotechnol. 2012, 23, 562-569. [CrossRef]

59. Pope, G.A. Newly discovered submicron-scale weathering in quartz: Geographical implications. Prof. Geogr. 1995, 47, 375-387. [CrossRef]

60. Pope, G.A. Internal weathering in quartz grains. Phys. Geogr. 1995, 16, 315-338. [CrossRef]

61. Caplette, J.N.; Schindler, M. Black rock-coatings in trail, british columbia, canda: Records of past emissions of lead, zinc, antimony, arsenic, tellurium, tin, selenium, silver, bismuth, and indium-bearing atmospheric contaminants. Can. Mineral. 2018, 56, 113-127. [CrossRef]

62. Mantha, N.M.; Schindler, M.; Murayama, M.; Hochella, M.F. Silica- and sulfate-bearing rock coatings in smelter areas: Products of chemical weathering and atmospheric pollution i. Formation and mineralogical composition. Geochim. Cosmochim. Acta 2012, 85, 254-274. [CrossRef]

63. Schindler, M.; Dorn, R.I. Rock and Mineral Coatings: Records of Climate Change, Pollution, and Life; GeoScienceWorld: McLean, VA, USA, 2017; p. 40.

64. Schindler, M.; Hochella Jr, M.F. Soil memory in mineral surface coatings: Environmental processes recorded at the nanoscale. Geology 2015, 43, 415-418. [CrossRef]

65. Mantha, H.; Schindler, M.; Hochella, M.F. Occurrence and formation of incidental metallic cu and cus nanoparticles in organic-rich contaminated surface soils in timmins, ontario. Environ. Sci. Nano 2019. [CrossRef]

66. Leverington, D.W.; Schindler, M. Delineating areas of past environmental degradation near smelters using rock coatings: A case study at rouyn-noranda, quebec. Sci. Rep. 2018, 8, 17364. [CrossRef] [PubMed]

67. Krinsley, D.H.; Dorn, R.I.; Tovey, N.K. Nanometer-scale layering in rock varnish: Implications for genesis and paleoenvironmental interpretation. J. Geol. 1995, 103, 106-113. [CrossRef]

68. Krinsley, D. Models of rock varnish formation constrained by high resolution transmission electron microscopy. Sedimentology 1998, 45, 711-725. [CrossRef]

69. Langworthy, K.; Krinsley, D.; Dorn, R.I. High resolution transmission electron microscopy evaluation of silica glaze reveals new textures. Earth Surf. Process. Landf. 2010, 35, 1615-1620. [CrossRef]

70. Ditto, J.; Krinsley, D.; Langworthy, K. Localized grounding, excavation, and dissection using in-situ probe techniques for focused ion beam and scanning electron microscopy: Experiments with rock varnish. Scanning 2012, 34, 279-283. [CrossRef]

71. Krinsley, D.; Ditto, J.; Langworthy, K.; Dorn, R.I.; Thompson, T. Varnish microlaminations: New insights from focused ion beam preparation. Phys. Geogr. 2013, 34, 159-173. [CrossRef]

72. Macholdt, D.S.; Jochum, K.P.; Pöhlker, C.; Stoll, B.; Weis, U.; Weber, B.; Muller, M.; Kappl, M.; Buhre, S.; Kilcoyne, A.L.D.; et al. Microanalytical methods for in-situ high-resolution analysis of rock varnish at the micrometer to nanometer scale. Chem. Geol. 2015, 411, 57-68. [CrossRef]

73. Garvie, L.A.J.; Burt, D.M.; Buseck, P.R. Nanometer-scale complexity, growth, and diagenesis in desert varnish. Geology 2008, 36, 215-218. [CrossRef]

74. Giorgetti, G.; Baroni, C. High-resolution analysis of silica and sulphate-rich rock varnishes from victoria land (antarctica). Eur. J. Mineral. 2007, 19, 381-389. [CrossRef]

75. Campbell, I.B.; Claridge, G.G.C. Antarctica: Soils, Weathering Processes and Environment; Elsevier: Amsterdam, The Netherlands, 1987; p. 367.

76. Mahaney, W.C.; Claridge, G.; Campbell, I.A. Microtextures on quartz grains in tills from antarctica. Palaeogeogr. Palaeoclimatol. Palaeoecol. 1996, 121, 89-103. [CrossRef] 
77. Talkington, R.W.; Mayewski, P.A.; Gaudette, H.E. Geochemical and glacio-geomorphic implications of basalt weathering in the queen maud mountains, antarctica. Geol. Mag. 1982, 119, 553-566. [CrossRef]

78. Gibson, E.K.; Wentworth, S.J.; McKay, D.S. Chemical weathering and diagenesis of a cold desert soil from wright valley, antarctica: An analog of martian weathering processes. J. Geophys. Res. Solid Earth 1983, 88, A912-A928. [CrossRef]

79. Salvatore, M.R.; Mustard, J.F.; Head, J.W.; Cooper, R.F.; Wyatt, M.B. Development of alteration rinds by oxidative weathering processes in beacon valley, antarctica, and implications for mars. Geochim. Cosmochim. Acta 2013, 115, 137-161. [CrossRef]

80. Watts, S.H. A scanning electron microscope study of bedrock microfractures in granites under high arctic conditions. Earth Surf. Process. Landf. 1985, 10, 61-172. [CrossRef]

81. Chevrier, V.; Mathé, P.E.; Rochette, P.; Gunnlaugsson, H.P. Magnetic study of an antarctic weathering profile on basalt: Implications for recent weathering on mars. Earth Planet. Sci. Lett. 2006, 244, 501-514. [CrossRef]

82. Cannon, K.M.; Mustard, J.F.; Salvatore, M.R. Alteration of immature sedimentary rocks on earth and mars: Recording aqueous and surface-atmosphere processes. Earth Planet. Sci. Lett. 2015, 417, 78-86. [CrossRef]

83. Mahaney, W.C.; Dohm, J.M.; Schwartz, S.; Findling, N.; Hart, K.M.; Conway, S.J.; Allen, C.C.; Miyamoto, H.; Fairén, A.G. Mineralogy, chemistry and biological contingents of an early-middle miocene antarctic paleosol and its relevance as a martian analogue. Planet. Space Sci. 2014, 104, 253-269. [CrossRef]

84. Bockheim, J.G. Properties of a chronosequence of ultraxerous soils in the trans-arctic mountains. Geoderma 1982, 28, 239-255. [CrossRef]

85. Bockheim, J.G. The Soils of Antarctica; Springer: Berlin, Germany, 2015.

86. Haus, N.W.; Wilhelm, K.R.; Bockheim, J.G.; Fournelle, J.; Miller, M. A case for chemical weathering in soils of hurd peninsula, livingston island, south shetland islands, antarctica. Geoderma 2016, 263, 185-194. [CrossRef]

87. Marra, K.R.; Madden, M.E.E.; Soreghan, G.S.; Hall, B.L. Chemical weathering trends in fine-grained ephemeral stream sediments of the mcmurdo dry valleys, antarctica. Geomorphology 2017, 281, 13-30. [CrossRef]

88. Lamp, J.L.; Mackay, S.L.; Head, J.W. Thermal stress weathering and the spalling of antarctic rocks. J. Geophys. Res. Earth Surface 2017, 122, 3-24. [CrossRef]

89. Krinsley, D.; Dorn, R.I.; DiGregorio, B.E. Astrobiological implications of rock varnish in tibet. Astrobiology 2009, 9, 551-562. [CrossRef] [PubMed]

90. Bockheim, J.G. Evolution of desert pavements and the vesicular layer in soils of the transantarctic mountains. Geomorphology 2010, 118, 433-443. [CrossRef]

91. Brown, D.J.; Lee, M.R. From microscopic minerals to global climate change? Geol. Today 2007, 23, $172-177$. [CrossRef]

92. Goldstein, J.; Newbury, D.E.; Joy, D.C.; Lyman, C.E.; Echlin, P.; Lifshin, E.; Sawyer, T.L.; Michael, J.R. Scanning Electron Microscopy and X-ray Microanalysis; Elsevier: Amsterdam, The Netherlands, 2003; p. 586.

93. Overwijk, M.H.F.; Van den Heuvel, F.C.; Bulle-Lieuwma, C.W.T. Novel scheme for the preparation of transmission electron microscopy specimens with a focused ion beam. J. Vacuum Sci. Technol. B Microelectron. Nanometer Struct. Process. Meas. Phenom. 1993, 11, 2021-2024. [CrossRef]

94. Burnett, T.L.; Kelley, R.; Winiarski, B.; Contreras, L.; Daly, M.; Gholinia, A.; Burke, M.G.; Withers, P.J. Large volume serial section tomography by xe plasma fib dual beam microscopy. Ultramicroscopy 2016, 161, 119-129. [CrossRef]

95. Dorn, R.I.; Gordon, M.; Pagán, E.O.; Bostwick, T.W.; King, M.; Ostapuk, P. Assessing early spanish explorer routes through authentication of rock inscriptions. Prof. Geogr. 2012, 64, 415-429. [CrossRef]

96. Dorn, R.I. Rock Coatings; Elsevier: Amsterdam, The Netherlands, 1998; p. 429.

97. Fleisher, M.; Liu, T.; Broecker, W.; Moore, W. A clue regarding the origin of rock varnish. Geophys. Res. Lett. 1999, 26, 103-106. [CrossRef]

98. Spilde, M.N.; Melim, L.A.; Northrup, D.E.; Boston, P.J. Anthropogenic lead as a tracer for rock varnish growth: Implications for rates of formation. Geology 2013, 41, 263-266. [CrossRef]

99. Zerboni, A. Holocene rock varnish on the messak plateau (libyan sahara): Chronology of weathering processes. Geomorphology 2008, 102, 640-651. [CrossRef]

100. Vázquez-Selem, L.; Heine, K. Late quaternary glaciation of mexico. In Developments in Quaternary Sciences; Elsevier: Amsterdam, The Netherlands, 2004; pp. 233-242. 
101. Dorn, R.I.; Phillips, F.M.; Zreda, M.G.; Wolfe, E.W.; Jull, A.J.T.; Kubik, P.W.; Sharma, P. Glacial chronology of mauna kea, hawaii, as constrained by surface-exposure dating. Natl. Geogr. Res. Explor. 1991, 7, 456-471.

102. Krinsley, D.; Dorn, R.I.; Anderson, S. Factors that may interfere with the dating of rock varnish. Phys. Geogr. 1990, 11, 97-119. [CrossRef]

103. Krinsley, D.H.; Dorn, R.I.; DiGregorio, B.E.; Langworthy, K.A.; Ditto, J. Rock varnish in new york: An accelerated snapshot of accretionary processes. Geomorphology 2012, 138, 339-351. [CrossRef]

104. Murdoch, J.; Webb, R.W. Minerals of california, centennial volume (1866-1966). Calif. Div. Mines Geol. Bull. 1966, 189, 1-344.

105. Weed, R.; Ackert, R.J. Chemical weathering of beacon supergroup sandstones and implications for antarctic glacial chronology. S. Afr. J. Sci. 1986, 82, 513-516.

106. Yesavage, T.; Thompson, A.; Hausrath, E.M.; Brantley, S.L. Basalt weathering in an arctic mars-Analog site. Icarus 2015, 254, 219-232. [CrossRef]

107. Mergelov, N.S.; Goryachkin, S.V.; Shorkunov, I.G.; Zazovskaya, E.P.; Cherkinsky, A.E. Endolithic pedogenesis and rock varnish on massive crystalline rocks in east antarctica. Eurasian Soil Sci. 2012, 45, 901-917. [CrossRef]

108. Dorn, R.I. Formation of silica glaze rock coatings through water vapor interactions. Phys. Geogr. 2012, 33, 21-31. [CrossRef]

109. Aulinas, M.; Garcia-Valles, M.; Fernandez-Turiel, J.L.; Gimeno, D.; Saavedra, J.; Gisbert, G. Insights into the formation of rock varnish in prevailing dusty regions. Earth Surf. Process. Landf. 2015, 40, 447-458. [CrossRef]

110. Dorn, R.I.; Krinsley, D.H.; Langworthy, K.A.; Ditto, J.; Thompson, T.J. The influence of mineral detritus on rock varnish formation. Aeolian Res. 2013, 10, 61-76. [CrossRef]

111. Strini, A.; Guglielmin, M.; Hall, K. Tafoni development in a cryotic environment: An example from northern victoria land, antarctica. Earth Surf. Process. Landf. 2008, 33, 1502-1519. [CrossRef]

112. French, H.M.; Guglielmin, M. Observations on granite weathering phenomena, mount keinath, northern victoria land, antarctica. Permafr. Periglac. Process. 2002, 13, 231-236. [CrossRef]

113. Guglielmin, M.; Cannone, N.; Strini, A.; Lewkowicz, A.G. Biotic and abiotic processes on granite weathering landforms in a cryotic environment, northern victoria land, australia. Permafr. Periglac. Process. 2005, 16, 69-85. [CrossRef]

114. Hall, K.; Guglielmin, M.; Strini, A. Weathering of granite in antarctica: I. Light penetration into rock and implications for rock weathering and endolithic communities. Earth Surf. Process. Landf. 2008, 33, $295-307$. [CrossRef]

115. Hall, K.; Guglielmin, M.; Strini, A. Weathering of granite in antarctica: Ii. Thermal stress at the grain scale. Earth surface processes and landforms. Earth Surf. Process. Landf. 2008, 33, 475-493. [CrossRef]

116. Boger, P.D.; Boger, J.L.; Jones, L.M.; Faure, G. Effect of chemical weathering on the rb-sr date of feldspar in neogene till, mount fleming, south victoria land, antarctica. Chem. Geol. 1987, 65, 35-44. [CrossRef]

117. Weed, R.; Norton, S.A. Siliceous crusts, quartz rinds and biotic weathering of sandstones in the cold desert of antarctica. In Diversity of Environmental Biogeochemistry (Developments in Geochemistry, Volume 6); Berthelin, J., Ed.; Elsevier: Amsterdam, The Netherlands, 1991; pp. 327-339.

118. Washburn, A.L. Desert varnish. In Weathering, Frost Action and Patterned Ground in the Mesters District, Northeast Greenland; Washburn, A.L., Ed.; Reitzels: Copenhagen, Denmark, 1969; pp. 14-15.

119. Douglas, G.R. Manganese-rich rock coatings from iceland. Earth Surf. Process. Landf. 1987, 12, $301-310$. [CrossRef]

120. Dorn, R.I.; Krinsley, D.H.; Liu, T.; Anderson, S.; Clark, J.; Cahill, T.A.; Gill, T.E. Manganese-rich rock varnish does occur in antarctica. Chem. Geol. 1992, 99, 289-298. [CrossRef]

121. Marnocha, C.; Dixon, J.C. Bacterial communities in $\mathrm{fe} / \mathrm{mn}$ films, sulphate crusts, and aluminium glazes from swedish lapland: Implications for astrobiology on mars. Int. J. Astrobiol. 2013, 12, 345-356. [CrossRef]

122. Lebedeva, M.P.; Golovanov, D.L.; Shishkov, V.A.; Ivanov, A.L.; Abrosimov, K.M. Microscopic and tomographic studies for interpreting the genesis of desert varnish and the vesicular horizon of desert soils in mongolia and the USA. Bol. Soc. Geol. Mexicana 2019, 71, 21-42.

123. Dorn, R.I.; Cahill, T.A.; Eldred, R.A.; Gill, T.E.; Kusko, B.; Bach, A.; Elliott-Fisk, D.L. Dating rock varnishes by the cation ratio method with pixe, icp, and the electron microprobe. Int. J. PIXE 1990, 1, 157-195. [CrossRef]

124. Tazaki, K. Formation of banded iron-manganese structures by natural microbial communities. Clays Clay Miner. 2000, 48, 511-520. [CrossRef] 
125. Villalobos, M.; Toner, B.; Bargar, J.; Sposito, G. Characterization of the manganese oxide produced by pseudomonas putida strain mnb1. Geochim. Cosmochim. Acta 2003, 67, 2649-2662. [CrossRef]

126. Krinsley, D.H.; Dorn, R.I.; DiGregorio, B.E.; Razink, J.; Fisher, R. Mn-fe enhancing budding bacteria in century-old rock varnish, erie canal, new york. J. Geol. 2017, 125, 317-336. [CrossRef]

127. Vázquez-Ortega, A.; Fein, J.B. Thermodynamic modeling of mn (ii) adsorption onto manganese oxidizing bacteria. Chem. Geol. 2017, 464, 147-154. [CrossRef]

128. Hartshorne, R.S.; Reardon, C.L.; Ross, D.; Nuester, J.; Clarke, T.A.; Gates, A.J.; Mills, P.C.; Frederickson, J.K.; Zachara, J.M.; Shi, L.; et al. Characterization of an electron conduit between bacteria and the extracellular environment. Proc. Natl. Acad. Sci. USA 2009, 106, 22169-22174. [CrossRef]

129. Potter, R.M. The Tetravalent Manganese Oxides: Clarification of Their Structural Variations and Relationships and Characterization of Their Occurrence in the Terrestrial Weathering Environment as Desert Varnish and Other Manganese Oxides. Ph.D. Thesis, California Institute of Technology, Pasadena, CA, USA, 1979.

130. McKeown, D.A.; Post, J.E. Characterization of manganese oxide mineralogy in rock varnish and dendrites using x-ray absorption spectroscopy. Am. Mineral. 2001, 86, 701-713. [CrossRef]

131. Liu, T.; Broecker, W.S. Millennial-scale varnish microlamination dating of late pleistocene geomorphic features in the drylands of western USA. Geomorphology 2013, 187, 38-60. [CrossRef]

132. Liu, T.; Broecker, W.; Stein, M. Rock varnish evidence for a younger dryas wet event in the dead sea basin. Geophys. Res. Lett. 2013, 40, 2229-2235. [CrossRef]

133. Liu, T. Vml Dating Lab. Available online: http:/ /www.vmldating.com/ (accessed on 17 November 2017).

134. Glasby, G.P.; McPherson, J.G.; Kohn, B.P.; Johnston, J.H.; Keys, J.R.; Freeman, A.G.; Tricker, M.J. Desert varnish in southern victoria land, antarctica. N. Z. J. Geol. Geophys. 1981, 24, 389-397.

135. Johnston, J.H.; Cardile, C.M. The characterisation of the iron oxide phase in desert varnish from antarctica using backscattered conversion electron and X-ray mössbauer spectroscopy. Chem. Geol. 1984, 45, 73-90. [CrossRef]

136. Baker, B.J.; Banfield, J.F. Microbial communities in acid mine drainage. FEMS Microb. Ecol. 2003, 44, $139-152$. [CrossRef]

137. Fein, J.B.; Brady, P.V.; Jain, J.C.; Dorn, R.I.; Lee, J. Bacterial effects on the mobilization of cations from a weathered pb-contaminated andesite. Chem. Geol. 1999, 158, 189-202. [CrossRef]

138. Dorn, R.I. Anthropogenic interactions with rock varnish. In Biogeochemical Cycles: Anthropogenic and Ecological Drivers; Dontsova, K., Balogh-Brunstad, Z., Le Roux, G., Eds.; American Geophysical Union: Washington, DC, USA, 2019.

139. Black, J.L.; MacLeod, I.D.; Smith, B.W. Theoretical effects of industrial emissions on colour change at rock art sites on burrup peninsula, western australia. J. Archaeol. Sci. Rep. 2017, 12, 457-462. [CrossRef]

140. Sims, D.B.; Hudson, A.C.; Keller, J.E.; Konstantinos, V.I.; Konstantinos, M.P. Trace element scavenging in dry wash surficial sediments in an arid region of southern nevada, USA. Mine Water Environ. 2017, 36, 124-132. [CrossRef]

141. Hoar, K.; Nowinski, P.; Hodge, V.F.; Cizdziel, J.V. Rock varnish: A passive forensic tool for monitoring recent air pollution and source identification. Nuclear Technol. 2011, 175, 351-359. [CrossRef]

142. Nowinski, P. Desert Varnish as an Indicator of Modern-Day Air Pollution in Southern Nevada. Ph.D. Thesis, Environmental Science, University of Nevada Las Vegas, Las Vegas, NV, USA, 2009; p. 209.

143. Nowinski, P.; Hodge, F.W.; Gerstenberger, S.; Cizdziel, J.V. Analysis of mercury in rock varnish samples in areas impacted by coal-fired power plants. Environ. Pollut. 2013, 179, 132-137. [CrossRef]

144. Hodge, V.F.; Farmer, D.E.; Diaz, T.A.; Orndorff, R.L. Prompt detection of alpha particles from po-210: Another clue to the origin of rock varnish? J. Environ. Radioact. 2005, 78, 331-342. [CrossRef] [PubMed]

145. Goldsmith, Y.; Stein, M.; Enzel, Y. From dust to varnish: Geochemical constraints on rock varnish formation in the negev desert, israel. Geochim. Cosmochim. Acta 2014, 126, 97-111. [CrossRef]

146. Getty, S.R.; Gutzler, D.S.; Asmerom, Y.; Shearer, C.K.; Free, S.J. Chemical signals of epiphytic lichens in southwestern north america; natural versus man-made sources for airborne particulates. Atmos. Environ. 1999, 33, 5095-5104. [CrossRef]

147. Andersen, S.T. History of the terrestrial environment in the quaternary of denmark. Bull. Geol. Soc. Den. 1994, 41, 219-228. 
148. Potapowicz, J.; Szumińska, D.; Szopińska, M.; Polkowska, Ż. The influence of global climate change on the environmental fate of anthropogenic pollution released from the permafrost: Part i. Case study of antarctica. Sci. Total Environ. 2019, 651, 1534-1548. [CrossRef] [PubMed]

149. Perdrial, N.; Liewig, N.; Delphin, J.-E.; Elsass, F. Tem evidence for intracellular accumulation of lead by bacteria in subsurface environmentsl. Chem. Geol. 2008, 253, 196-204. [CrossRef]

150. Villalobos, M.; Bargar, J.; Sposito, G. Trace metal retention on biogenic manganese oxide nanoparticles. Elements 2005, 1, 223-226. [CrossRef] 